\title{
Avrupa Ülkelerinde Kullanılan Tarih Atlaslarından Örnekler
}

\section{Examples of History Atlases Used in the European Countries}

\author{
Hamide KILIÇ \\ İstanbul Üniversitesi-Cerrahpaşa, H. Ali Yücel Eğitim Fakültesi, E-posta: hamide.kilic@istanbul.edu.tr \\ orcid.org/0000-0002-4034-1948
}

Article Info

\begin{tabular}{|c|c|}
\hline Article Type & Research \& Theoretical \\
\hline Received & 29.09.2019 \\
\hline Accepted & 08.03.2020 \\
\hline DOI & 10.17497/tuhed.626362 \\
\hline $\begin{array}{l}\text { Corresponding } \\
\text { Author }\end{array}$ & Hamide KILIÇ \\
\hline Cite & $\begin{array}{l}\text { Kilıç, H. (2020). Avrupa ülkelerinde kullanılan tarih atlaslarından } \\
\text { örnekler. Turkish History Education Journal, } 9 \text { (1), ss. 17-45. DOI: } \\
\text { 10.17497/tuhed.626362 }\end{array}$ \\
\hline
\end{tabular}


Öz: Tarih atlasları tarih öğretiminde başvurulacak yardımcı kaynakların başında gelmektedir. Tarih haritası, öğrenciyi metin içerisinden çıkararak konu edilen olay ya da olgunun mekânsal boyutunu, incelenen döneme göre zamansal boyutunu ve şekiller ve semboller aracılığıyla da ilişkisel boyutunu görsel olarak öğrenciye sunar. Çalışmanın temel amacı çeşitli Avrupa ülkelerinde tarih öğretiminde kullanılan tarih atlasları arasından farklı olanları okuyucuya sunarak, tarih öğretimi ile ilgilenen araştırmacı ve eğitimcilere, bu alanda ders materyali hazırlayan ders kitabı yazarlarına ve tarih öğretmenlerine değişik örnekler göstermektir. Çalışmanın çıkış noktası, farklı ülkelerde okutulan tarih atlaslarında ne tür tarih haritaları kullanılmaktadır, farklı haritalar ve anlatımlar var mıdır, sorularından hareketle oluşmuştur. Macaristan, Hollanda, İtalya, İspanya, Belçika, Almanya, Fransa, Arnavutluk, Sırbistan, İsviçre, İsveç, Norveç, Litvanya, Avusturya, Rusya, Polonya tarih atlasları başta olmak üzere Georg Eckert Ders Kitapları Enstitüsü (Almanya) nde bulunan tarih atlaslarının birçoğu incelenmiştir. İncelenen tarih atlaslarından alışılagelmişten farklı tarih haritaları dokuz tema altında toplanmıştır: Tarih öncesi dönemler ve evrim, Yazı/Alfabe, Dinler, Bilimsel faaliyetler ve teknik gelişmeler, Beşerî faaliyetler, Salgın hastalıklar, Uluslararası örgütler, Nüfus, Günümüz dünya sorunları. Taranan tüm tarih atlaslarında başlangıç bölümü "Evrim Teorisi" ne ayrılmıştır. Bunun yanı sıra yazı ve geçirdiği değişimleri, insanların yaptıkları her türlü beşerî faaliyetleri anlatan haritalar alışılagelmiş savaş ve anlaşma haritalarının dışında oldukça dikkat çekmektedir. Avrupa ülkelerinde okutulan atlaslarda iklim değişiklikleri, nüfus hareketleri, dünya üzerinde yaşanan çatışmalar ve uluslararası örgütlerin müdahaleleri gibi tematik tarih haritaları da kullanılmaktadır.

Anahtar Kelimeler: Tarih Atlası, Tarih Haritası, Tarih Eğitimi, Tarihi Olay, Tarihi Olgu

\begin{abstract}
History atlases are one of the important resources for history education. It allows students to study with groups in-class activities or by themselves at home. A history map is a visual representation of the theme or event, that provides the students spatial dimension with the visual illustration, temporal dimension according to the period, and relational dimension through shapes and symbols. The main aim of the study is to present different examples of historical atlases used in various European countries to readers, researchers and teachers who interested in history education. For this purpose, many history atlases from European countries like Norway, Sweden, Spain, Italy, Hungary, Serbia, Russia, Albania, France, so on in Georg Eckert Institute were scanned and different historical maps were selected. In this study, different history maps are gathered under nine themes: Prehistoric periods and evolution, Alphabet, Religions, Scientific and technological developments, Human activities, Epidemic diseases, International organizations, Population, Contemporary world issues. The theory of evolution is the beginning of all history atlases which scanned at this study. In addition to this, the maps about the alphabet and all kinds of human activities are noticeable differences in historical atlases. Thematic history maps are also used in European countries such as climate changes, population movements, conflicts around the world and interventions of international organizations.
\end{abstract}

Keywords: History Atlas, History Map, History Education, Historical Event, Historical Phenomenon

\title{
Extended Summary
}

\section{Purpose}

The main aim of the study is to present different examples of historical atlases used in various European countries to readers, researchers and teachers who interested in history education. For this purpose, many history atlases from European countries like Norway, 
Sweden, Spain, Italy, Hungary, Serbia, Russia, Albania, France, so on at Georg Eckert Institute were scanned and different historical maps were selected for giving an idea about using history maps at history education.

\section{Method}

In the study, the document analysis method was used. In this context, 17 history atlases used from primary school to high school in various European countries were scanned. History atlases from the following countries are included in this study: Norway, Belgium, Italy, Spain, Sweden, Switzerland, France, Poland, Hungary, Serbia, Denmark, Netherlands and Lithuania. Then they are gathered under nine themes: Prehistoric periods and evolution (3), Alphabet (3), Religions (4), Scientific and technological developments (4), Human activities (4), Epidemic diseases (2), International Organizations (2), Population (2), and Contemporary world issues (2). In the study selected 29 maps and 10 other figures (legends, timelines) were examined.

\section{Results and Discussion}

In this section, the results of the study will be presented under nine themes.

Historical maps about prehistoric periods and evolution: The Theory of Evolution is the first part of the history atlases which have been scanned for this study. Four figures from France, Serbia and Hungary and one history map from Hungarian history atlases are presented in the study. The figures describe not only human evolution but also the evolution of other species like animals and plants.

Historical maps about the alphabet: Three history maps from Belgium, Denmark and Poland and one legend from Poland's history atlases are presented. The maps examine which alphabets are related and how they are affected by each other.

Historical maps about religions: Four history maps from Norway, Spain, Italy and Hungary are selected for the study. History map from Norway examines religions in today's World. The map from Hungary is about Islamic culture from the $7^{\text {th }}$ to $13^{\text {th }}$ centuries. On this map, scholars of literature, philosophy, mathematics and geography fields such as al-Kindi, alFarabi, Harezmi, and Tabari as well as samples of Islamic culture were presented.

Historical maps about scientific and technological developments: Five history maps from Lithuania, Poland, France and Hungary and one figure from Hungary are indicated. The maps from Lithuania and France present the universities in Europe. The map from Hungary presents the development in the field of science and art and important scientist, artists and their works from the $15^{\text {th }}$ century to the $18^{\text {th }}$ century in Europe.

Historical maps about human activities: Human activities like agriculture, planting, farming or economic activities can be subject to historical maps. In this context, four maps from Serbia, Poland, and Hungary are selected for the study. The map from Poland shows the beginning of agricultural activities in the World. Especially the symbols used in the legends of this map are quite noticeable. 
Historical maps about epidemic diseases: Epidemic diseases can also be subject to history atlases. There are four maps from Switzerland history atlases. The maps are about Cholera, Influenza, AIDS, Tuberculosis and Malaria.

Historical maps about international organizations: Some history atlases included maps about international organizations and their activities. Three maps and two figures from Netherlands and Switzerland history atlases are selected for this study. The first map is about the European Union and it's development process. Second is about the United Nations and the areas of the United Nations' intervention in the World. The last one is about the places where the Netherlands sent troops in the United Nations between 1950-2010.

Historical maps about population: There are two maps from Spain and Belgium history atlases. The map from Spain examines population movement between 1940-1975 in Spain. The map from Belgium indicates the population movement in the World since 1990.

Historical maps about contemporary world issues: Contemporary Word issues like climate change and environmental issues, migration movements and nuclear energy can be subject to a historical atlas. In the study, three maps from Spain's and Switzerland's history atlases are examined.

\section{Conclusion}

History atlas is one of the important resources for history education. It allows students to study with groups at class activities or by themselves at home. A history map is a visual representation of the theme or event, that provides the students spatial dimension with the visual illustration, temporal dimension according to the period, and relational dimension through shapes and symbols.

Using the map is a complex activity that contains map reading, map analysis and map interpretation. Some sub-skills in map use can also be listed: using symbols, finding location, orienting and using directions, using scale and finding distance and selecting media. In a study conducted with fifteen kindergartens in Sofia showed that children were able to read maps. The study revealed that they had already learned the continent names, the borders and cities of Bulgaria, the names of the great mountains and rivers.

The examples examined in the study show that different themes can be subject to a history atlas according to the holistic view. From the alphabet to technological developments or epidemic diseases to human activities, a specific issue can become to the fore depending on the place and time. In this context, the maps about the alphabet and all kinds of human activities are noticeable differences in the history atlases. History maps such as climate change, population movements, conflicts and interventions by international organizations are also very different maps that we did not use to. In addition, the maps in the history atlases must be prepared differently for each grade and contained different features. 


\section{Giriş}

Insanoğlu tarih öncesi dönemlerde yaşadığı yerleri, avladıkları hayvanları, başına gelen birçok olayı mağara duvarlarına resmetmiştir. Bu duvar resimleri haritacılığın ilk örnekleri olarak düşünüldüğünde; o tarihlerden günümüze kadar evrilen haritaların belirli bir yer, zaman ve amaç için hazırlandığını bilmek gerekmektedir. Her harita sahip olduğu ölçek, boyut ve çeşitli sembollerle bir yer ve o yerin özelliklerini ve sunduğu dönemle ilişkilerini içermektedir (Smart, 2014:15). Haritalar bir yerin bahsettiği konuya göre birçok bilgiyi sunarken her türlü bilgiyi de barındırmaz; yani her harita konu ile ilişkili unsurları sunduğu ölçüde okunur ve anlaşııırdır.

Atlaslar kütüphanelerde mutlaka olması gereken, okullarda olmazsa olmaz, öğretmenler için yararlı bir öğretim materyalidir (Tulasne, 2015:31). Tarih öğretiminde de atlaslar ilk akla gelen yardımcı materyallerdendir. Birçok öğrencinin okul çantasında tarih ders kitaplarının yanında "Tarih Atlası" da bulunur. Tarih atlasları öğrencinin sınıf içi etkinliklerde ve evde çalışma yapmasına olanak sağlar.

Haritacılara göre haritalama; görselleştirme, kavramsallaştırma, yeniden düzenleme, temsil etme ve grafik olarak yaratma eylemlerini içermektedir (Boehm, 2004:44-45). Harita, okuyucunun farklı bilgi türlerini ayırt etmesine yardımcı olarak semboller kullanır. Her sembolün anlamı da harita lejantı/anahtarında açıklanır (Boehm, 2004:31). Bu bakımdan bir tarih haritası, öğrenciyi metin içerisinden çıkararak konu edilen olay ya da olgunun mekânsal boyutunu, incelenen döneme göre zamansal boyutunu ve şekiller ve semboller aracıllğıyla da ilişkisel boyutunu görsel olarak öğrenciye sunar. Bu bağlamda da haritalar, grafik ve tablolardan ayrı bir özellik taşır. Tablolar ve grafikler sayılar anlamına gelirken; öğrenci tabloya bakarak bu sayılardan yola çıkarak bahsedilen konu ya da olgu hakkında artmış ya da azalmış gibi yorumlarda bulunabilir. Aynı konu ya da olguya ait haritada ise öğrenci öncelikle konu/olgunun kime ait olduğunu mekânsal olarak görür. Bunun yanında gerçek hayattan bir yer sunulduğu için gerçeklik boyutu da öğrenciyi dikkatli kılar. Sunulan sembol ve şekiller, kullanılan renkler, farklı açılardan öğrencinin bunları yorumlamasına da olanak sağlar. Örneğin her sembolün birbiri ile olan ilişkisi, sembollerin gösterildiği yerlerdeki coğrafi konum, gölgelendirme ya da renklendirme yoluyla gösterilen yükseklik ve yeryüzü şekilleri öğrencinin öğrendiği konu/olgunun görsel bir özeti gibidir.

Coğrafya ve tarih eğitimine yardımcı olmak için haritacılar çeşitli haritalar hazırlamaktadır: Duvar haritaları, atlas, elektronik atlas, kör/dilsiz haritalar, küreler, görsel kartografik sunumlar, vs. Harita etkinliklerinde temel sorun harita okumalarına çocukların hangi yaştan itibaren başlayacağıdır. Günümüzde çocuklar medya, internet, televizyon aracılığıyla her gün yeni bilgilere ulaşabilmektedir. Bu durumda aslında çocuklar okul öncesi dönemden itibaren haritalarla da karşılaşmaktadır. Sofya'da 15 anaokulunda yapılan çalışmada çocukların haritaları okuyabildikleri anlaşılmıştır. Yapılan çalışmayla, çocukların kıta adlarını, Bulgaristan'ın sınırlarını ve şehirlerini, büyük dağların ve nehirlerinin adlarını daha önceden öğrendikleri ortaya çıkmıştır (Bandrova, 2012: 205-206). 
Değişen eğitim anlayışları ve gelişen teknolojiye bağlı olarak tarih atlaslarında da yeni yaklaşımlar oluşmaktadır. Eski tarih atlasları hakkında öğretmenlerden gelen genel şikâyet, çok fazla sembol ve bilginin iç içe verilmesi olarak ifade edilirken yeni yaklaşıma göre tarih atlasları aşağıda yer alan şu özelliklere göre oluşturulmaya çalışılmaktadır (Bandrova, 2012, 213-215):

- Net, genel, temel coğrafi bilgi: Sadece en büyük nehirler ve konuya uygun olanlar seçilmeli ve gölgelendirme ve renklendirmelerle yeryüzü şekilleri sunulmalı,

- Aynı konuların farklı sunumları farklı sınıf düzeyleri için oluşturulmalı,

- Genel lejantta çok fazla sembol olmamalı, sadece çok ilgili olanlar lejanta konulmalı.

Haritaları anlamak için haritalarda mevcut olan bazı sembolleri ve anahtarları bilmek gerekmektedir. Tüm haritalar (coğrafya ve tarih) bazı önemli anahtarlara sahiptir. Bu haritalar konum (yer) ve nitelikle (ne anlattığı) ilgilidirler ve gerçekliğin küçültülmüş halidir (ölçek) (Wiegand, 2006: 9).

Akengin (2015:129) tarih öğretiminde kullanılan haritalar hakkında yaptığı çalışmasında, tarihi olayların anlatılmasında büyük rol oynayan haritalarla tarih öğretiminin ezber ve hikâye olmaktan çıkacağını belirtmektir. Tarih öğretiminde kullanılan haritalar üzerine ülkemizde yapılmış çalışmalardan etraflıca bahseden Akengin'e göre; haritalarda olması gereken özellikler şunlardır: Haritada mevcut şekil ve işaretleri açıklayan lejant, yönleri gösteren yön işareti, mesafeler konusunda çıkarımlarda bulunmayı sağlayacak ölçek, konumlandırma için paralel ve meridyenler. Bu çalışmada sunulan örneklerden bazı haritalarda Akengin'in belirttiği bu dört özellik yer bulurken (Fransa ve Belçika tarih atlasları) bazılarında söz konusu özelliklerden hiçbiri bulunmamaktadır.

Ülkemizde kullanılan tarih atlaslarının en yaygını Faik Reşit Unat tarafından hazırlanmış olan "Tarih Atlası" dır. Atlasın önsözünde Unat, Türk harfleri ile basılan bu ilk atlasın daha iyileri çıkana kadar tarih öğretiminde var olan boşluğu dolduracağını umduğunu ifade eder. Ayrıca atlasın kelimenin tam anlamıyla bir tarih atlası olduğunu da vurgular (1957 Baskısı Önsöz). Bahri Ata'nın çalışmasında (2009:99) Hocası Prof. Dr. Hüseyin Dağtekin'den aktardığına göre, Faik Reşit Unat 1952'de hazırladığı bu tarih atlasını Alman öğretmen ve kartograf Friedrich Wilhelm Putzger'in okul tarih atlası ve cumhuriyet tarihleri haritalarından yararlanarak hazırlamıştır.

Araştırmanın yapıldığı Georg Eckert Uluslararası Ders Kitapları Enstitüsünün Türkiye rafında Faik Reşat Unat'ın hazırladığı Tarih Atlasının 1957 baskısı (48 sayfa), 1967 baskısı (56 sayfa) ve 1999 baskısı (56 sayfa) bulunmaktadır. Bu tarih atlasından başka Türkiye rafında bulunan diğer tarih atlasları ise şunlardır:

- Ortaokul Sosyal Bilgiler Atlası, Mefaret Arkın- R. Gökalp Arkın, İstanbul: Arkın Kitabevi, 1978, 40 sayfa.

- Tarih Atlası, Baki Kurtuluş, Ankara: Kurtuluş Yayınları, 1979, 38 sayfa.

- Büyük Tarih Atlası, İstanbul: Arkın Kitabevi, 1982, 48 sayfa.

- Açıklamalı Tarih Atlası, Veli Şirin, İstanbul: Özyürek, 1999, 53 sayfa.

- IIlkçağ Tarih Atlası, Colin McEvedy, 2. Baskı, Çev. Ayşe Anadol, İstanbul: Sabancı Üniversitesi Yayınları, 124 sayfa. 
Çalışmanın amacı çeşitli Avrupa ülkelerinde tarih öğretiminde kullanılan tarih atlasları arasından farklı olanları okuyucuya sunarak, tarih öğretimi ile ilgilenen araştırmacı ve eğitimcilere, bu alanda ders materyali hazırlayan ders kitabı yazarlarına ve tarih öğretmenlerine değişik örnekler göstermektir. Böylece ülkemizde yeterli ilgi görmeyen tarih atlaslarına dikkat çekerek; tarih haritalarının önemini vurgulamaktır. Çalışmada haritalarda olması gereken temel özelliklere bakılmamış; daha çok haritalarda konu edilen temalar ve bu temaları anlatmak için kullanılan imgeler yorumlanmaya çalışıımıştır.

\section{Yöntem}

Bu çalışmada Almanya Braunschweig'da bulunan Georg Eckert Uluslararası Ders Kitapları Enstitüsünde mevcut olan tarih atlasları incelenmiş ve alışılagelmişten farklı ve yaratıcı görünen harita örnekleri sunulmuştur. Georg Eckert Enstitüsü yaklaşık 175 ülkeden 180.000 basılı ve çevrimiçi tarih, coğrafya, sosyal bilimler alanındaki ders kitapları, yardımcı materyaller, müfredatlar ve yaklaşık 80.000 akademik basılı ve çevrimiçi araştırma kitaplarını içeren devasa bir koleksiyona sahiptir. Enstitünün kütüphanesi, birçok ülkenin ders kitapları ve yardımcı ders materyallerine sahip olduğundan dünyanın birçok ülkesinden gelen araştırmacılara bu kitapları inceleme ve kıyaslama imkanını sunmaktadır.

Alıştığımız tarih haritaları savaşları, ülkelerin kuruluş, gelişme ve yıkılma dönemleri, milletlerin yayılmaları gibi olay merkezli haritalardır. Bu haritalarda öğrencilerin ön bilgileri, yaş düzeyleri gibi faktörler dikkate alınmaksızın haritalar öğrenciye sunulmaktadır. Bu çalışmada olaydan ziyade olgulara holistik bakan tarih atlaslarının konularına dikkat çekilmiştir. Öncelikle Macaristan, Hollanda, Belçika, Fransa, Polonya, Norveç, İsveç, İsviçre, Romanya, İspanya gibi birçok ülkenin ilkokul ve ortaöğretimde kullanılan tarih atlasları tek tek incelenmiştir. Incelenen atlaslarda haritaların hangi konular üzerine yoğunlaştığı çalışmanın birinci aşamasını oluşturmaktadır. Ardından incelenen bu konuların nasıl sunulduğu, haritada kullanılan sembollerin çeşitliliği ve düzeylere göre değişimi incelenmiştir. Taranan tarih haritalarının çokluğu ve çalışmanın doğası gereği konular sınırlı tutulmuş; tarihin sadece savaşları ya da devletlerin kuruluş ya da yıkılışlarını konu edinmediğini gösteren hatta günümüzde birçok dünya sorununun da tarihin konusu olduğuna dikkat çeken haritalar seçilmiştir. Sunulan örneklerde gelişme, sosyal hayat, bilimde ilerleme, hastalık gibi pek çok haritanın seçilmiş olmasının temel nedeni tarihin, geçmişin ve bugünün her alanını konu edindiğini okura hatırlatmaktır. Çalışmada sunulan haritalar farklı ülkelerde kullanılan tarih atlaslarından alınmıştır. Duvar haritaları ve tarih ders kitaplarında yer alan haritalar incelenmemiştir. Gerekli verilerin tarih atlaslarının analizi yoluyla temin edildiği bu çalışma Etik Kurul Onayı gerektirmemektedir. 


\section{Bulgular}

Incelenen tarih atlasları ilkokuldan ortaöğretim düzeyine kadar farklı seviyelerde tarih atlaslarıdır. Bu atlaslar kimi zaman bütüncül bakış açısıyla, bahsedilen dönemdeki tüm dünya üzerinde konuyu (olay ya da olgu) gösterirken kimi zaman da sadece bir temayı sunan haritalardan oluşmaktadırlar. Bu çalışmada verilen örnekler konularına göre sınıflandırılmaya çalışılmıştır. Başııların sıralanmasında alfabetik sıralama yerine atlaslarda verilen kronolojik sıralama tercih edilmiş olup seçilen temalar şöyledir: Tarih öncesi dönemler ve evrim, Yazı/Alfabe, Dinler, Bilimsel ve teknolojik gelişmeler, Beşerî faaliyetler, Salgın hastalıklar, Uluslararası örgütler, Nüfus, Günümüz dünya sorunları.

\section{Tarih Öncesi Dönemler ve Evrim}

Georg Eckert Ders Kitapları Enstitüsünde incelenen tarih atlaslarında insanlığın ortaya çıkışı hakkında haritalar, görseller, farklı canlandırmalar ve bilgiler bulunmaktadır. İlk insan ve insanın evrimi hakkında ilkokul düzeyinden orta öğretime kadar tüm atlaslarda farklı görselleri görmek mümkündür. Evrim teorisini sunan bu görsellerde insan türü yanında diğer canlıların da evrimi gösterilir. Aşağıda sunulan Fransa tarih atlasında insan türünün evrimi, insanın beyninin gelişimi, her evrim dönemine rastgelen tarihi olaylar ve bu insan türlerinin dönemlere göre dünyada bulunduğu yerler gösterilmiştir:

Şekil 1. Australopithecus'tan Homosapiensé, Atlas Historique, Fransa (2000)

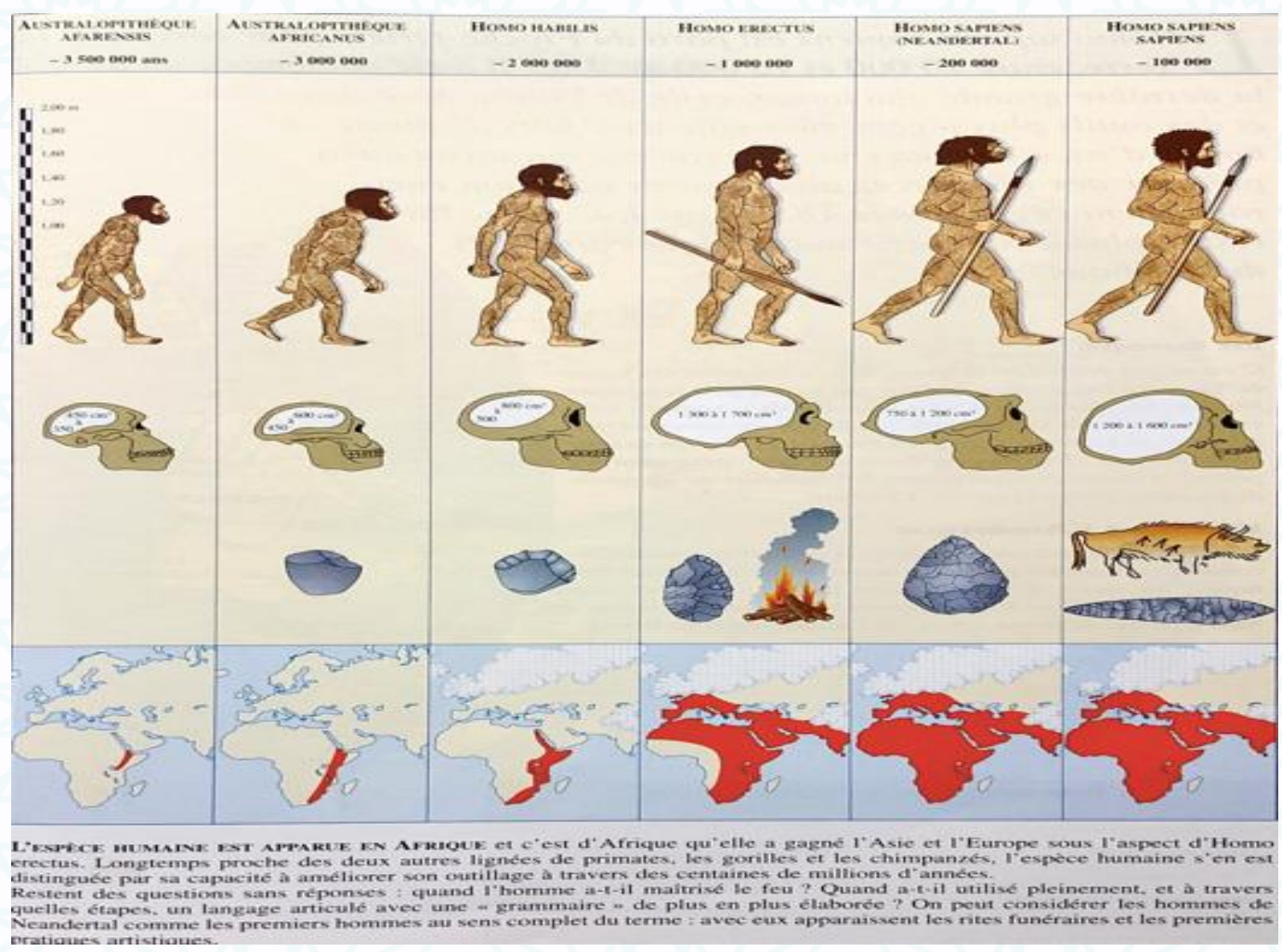

Şekil 1, harita ve şekillerden oluşmaktadır. Hemen altında ise insanın evrimi hakkında bilgi verilmiştir. Bu şekildeki harita incelendiğinde insan türünün başlangıçtaki yeri, yayılma alanı ve dönemlere göre nüfusun çoğalmasını görmek mümkündür. Ayrıca her dönemde yaşayan insan türü ile bu döneme ait gelişmelerin de yan yana sunulması, insanın yeryüzüne çıkışı ve 
tarih öncesi çağlardaki gelişmelerin özeti niteliğindedir. Görsel ve hemen altında verilen bilgi okurun başka kaynaklara başvurmadan dahi görseli yorumlamasına olanak sağlamaktadır. Görselde insan boyunun dönemlere göre uzaması, insanın vücudunun ve beyninin gelişimi, gelişime bağlı olarak yaşam şeklinin değişimi ve insan nüfusunun zamana göre çoğalması anlatılmaktadır. Görseller okurun gelişim, ilerleme, değişim ve çoğalma kavramlarının ilişkilendirebilmesine imkân vermektedir.

Sırbistan'da kullanılan ИСТОРИЈСКИ АТЛАС tarih atlasında da tarih şeridi şeklinde hazırlanan görselde insanın evrimi anlatılmaktadır:

Şekil 2. İlkel İnsan ve Doğa ile Mücadele, ИСТОРИЈСКИ АТЛАС, Sırbistan (2008)

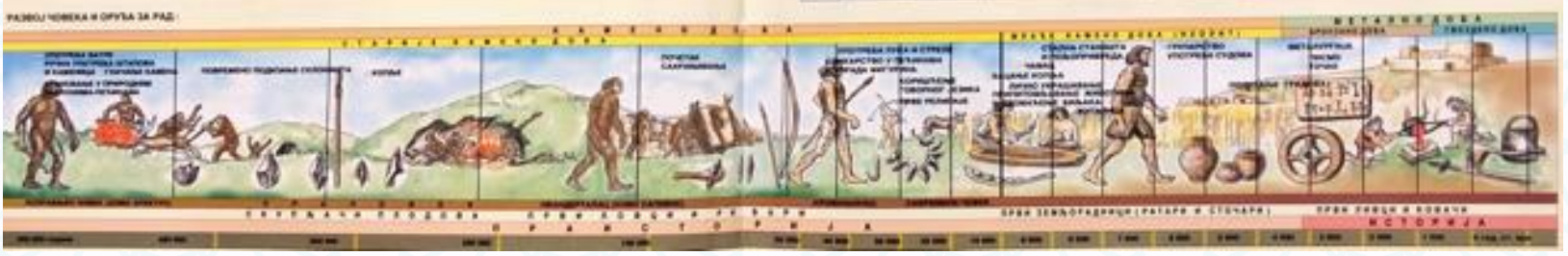

Şekil 2'deki bu tarih şeridinde tarih öncesi dönem, insanının ateşi bulması, avlanması, yerleşik hayata geçişi, yaptığı küçük aletler ve süs eşyaları, hayvanların evcilleştirmesi, yazının icadı, tekerleğin icadı, madenin işlenmesi, silahlar ve ilk yerleşimler canlandırılmıştır. Tüm şerit boyunca insan türünün evrimi ve dönemleri ve buna bağlı olarak gelişme ve değişim sunulmuştur.

Şekil 3. Insan ve Evrimi, ИСТОРИЈСКИ АТЛАС, Sırbistan (2008)

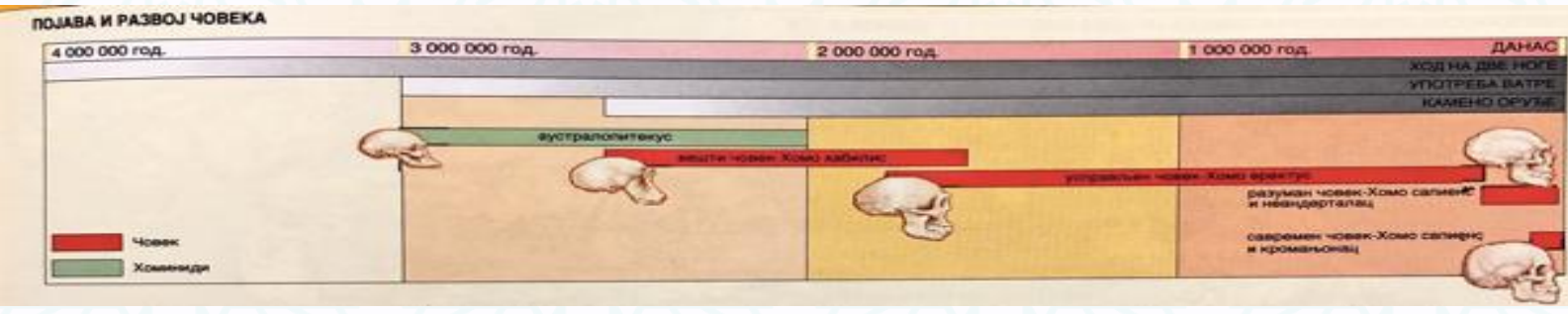

Şekil 3'te ise insan kafatasının her döneme göre gelişimi sunulmuştur. Şekil 3, bu tarih atlasında yukarıdaki tarih şeridinin hemen ardında yer almış; kafatasının gelişimi ile çeşitlenen ve çoğalan faaliyetler arasında öğrencinin ilişki kurulması amaçlanmıştır.

Képes történelmi atlasz (Macaristan)' da ise atlasın ilk sayfasında sunulan evrim konusu dönemlere göre hazırlanmış; insanın evrimi, insan türleri ve evriminin dönemleri, bitki ve hayvan türleri ve gelişim aşamaları da görsele konu edilmiştir: 
Şekil 4. Yerin Yaşam Tarihi ve Yaşayan Dünya, Képes történelmi atlasz, Macaristan (2001)

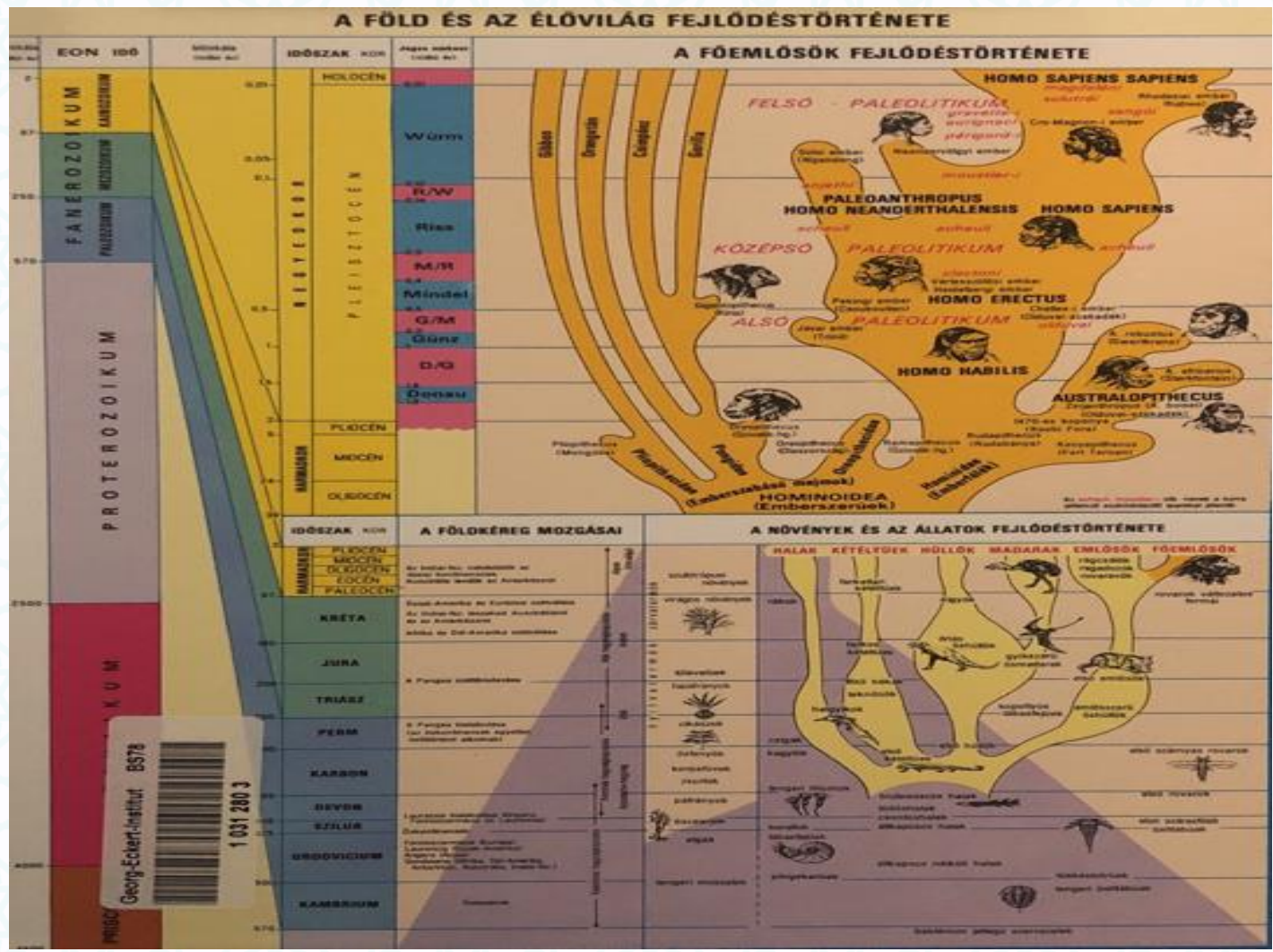

Şekil 4 incelendiğinde; jeolojik dönemler ve bu dönemlerdeki insan, hayvan ve bitki türlerinin gelişimi anlatılmaktadır. Bu görselin hemen ardından verilen haritada ise insan türlerinin dünyadaki yerleri ve yapılan faaliyetler yer almaktadır. Harita, okura tüm insan türlerinin nerelerde yaşadıkları, bu insanların o dönemlerde ne gibi faaliyetler yaptıkları hakkında bilgi sunarak okurun döneme bütüncül bakabilmesine de imkân vermektedir. Ayrıca haritada ölçek ve paralel ve meridyenler gibi harita özellikleri de kullanılmıştır:

Şekil 5. İnsan Faaliyetleri, Képes Történelmi Atlasz, Macaristan (2001)

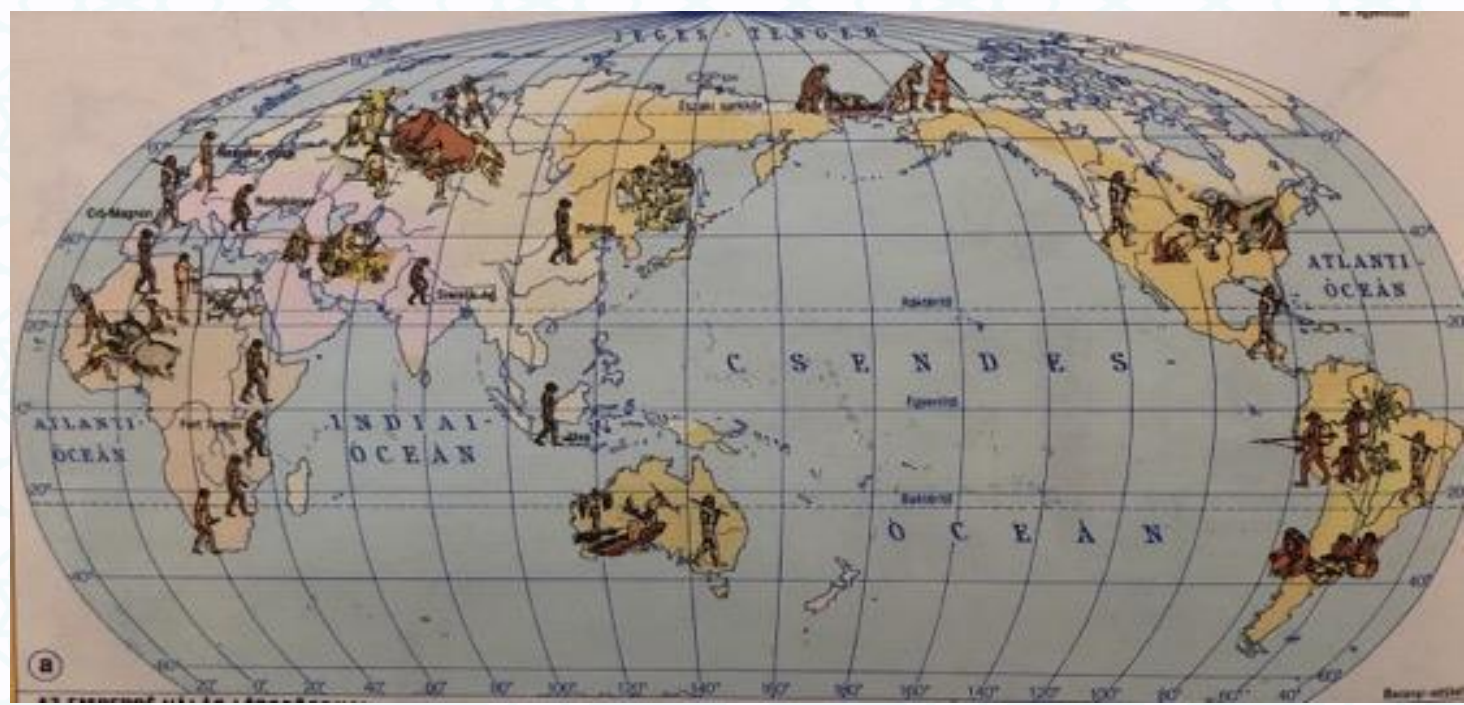


Şekil 5, insan türlerinin nerelerde bulunduğunun ve bulundukları mekânlarda yaptıkları beşerî faaliyetlerin canlandırmalarını içermektedir. Haritada lejant bulunmasa da canlandırmalar, okuyucuya bilgi vermektedir.

\section{Yazı/Alfabe:}

Tarih atlaslarında kullanılan yazı/alfabe haritaları oldukça dikkat çekicidir. Bu haritalarda yazı türleri, günümüzde kullandığımız alfabenin değişim süreci, kullanılan diğer alfabeler, hangi alfabenin hangi alfabelerle etkileşim içinde olduğu, alfabelerin kullanıldığı ve yayıldığı coğrafyalar gibi çeşitli bilgiler sunulmaktadır:

Şekil 6. Yazının Yayılması, Historiche Atlas, Belçika (2004)

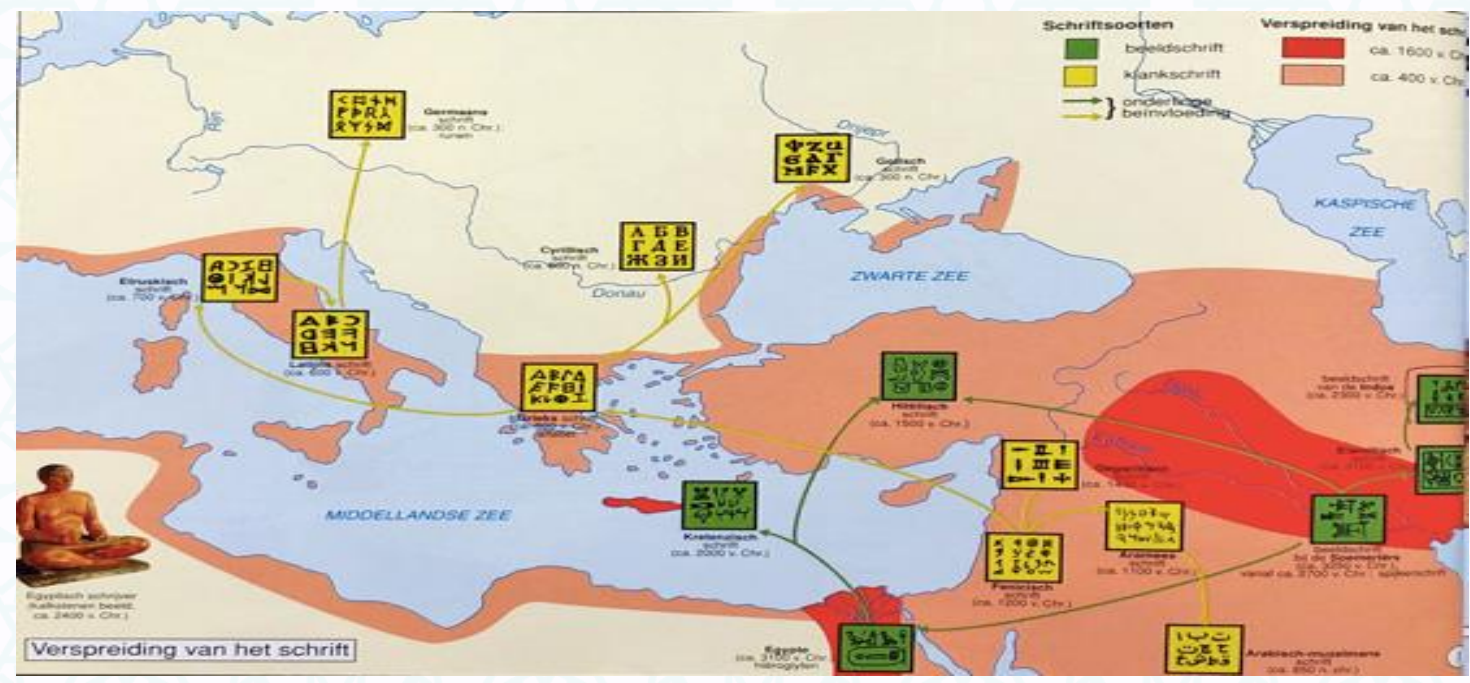

Yazı konusunda ilk harita örneği Belçika'da kullanılan L'atlas d'histoire (1998) tarih atlasında yer alır. Aynı harita Historiche Atlas (2004)'ta da bulunur. Her iki atlasın da hazırlayanı Xavier Adams olması kullanılan haritaların benzer olmasını açıklamaktadır. Şekil 6'nın lejantı incelendiğinde sarı ve yeşil renklerin yazı türlerini işaret ederken diğer renklerin ise zamana göre yazının yayılmasını ifade ettiği anlaşılmaktadır. Bununla beraber hangi alfabe hangisiyle ilişkilidir ve hangileri biri birlerinden etkilenmiştir gibi bilgiler de haritada sunulmaktadır. Ayrıca kullanılan alfabelerin işaretlerinin haritada gösterilmesi okura sunulan dikkat çekici bir bilgidir.

Şekil 7. Yazının Illk Türleri, Historisk Atlas, Danimarka (1998)

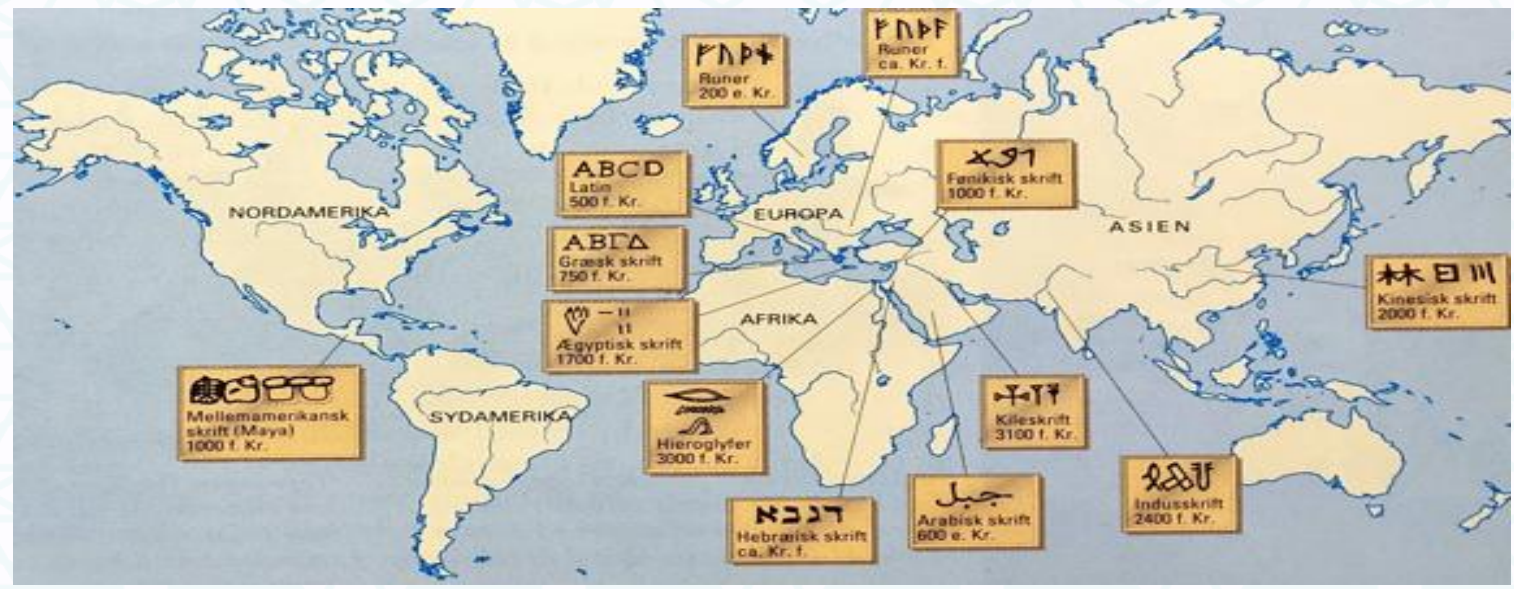


Benzer bir yazı haritası da Danimarka kullanılan Historisk Atlas (1998)'ta vardır. Şekil 7'de yazı türleri, nerelerde ve ne zaman ortaya çıtıtıkları ve alfabelerin şekilleri gösterilmektedir. Lejantın kullanılmadığı haritada, kutucuklar oklarla ait oldukları yerlere (konum) ilişkilendirilmiş, bu kutucuklar içinde küçük bilgiler verilmiştir. Ayrıca koordinat, yön ve ölçek gibi bilgiler bu haritada mevcut değildir.

Yazı haritalarına bir örnek de Polonya'da kullanılan Atlas Historyczny (2009) adlı tarih atlasından verilebilir:

Şekil 8. Yazının Doğuşu, Atlas Historyczny, Polonya (2009)

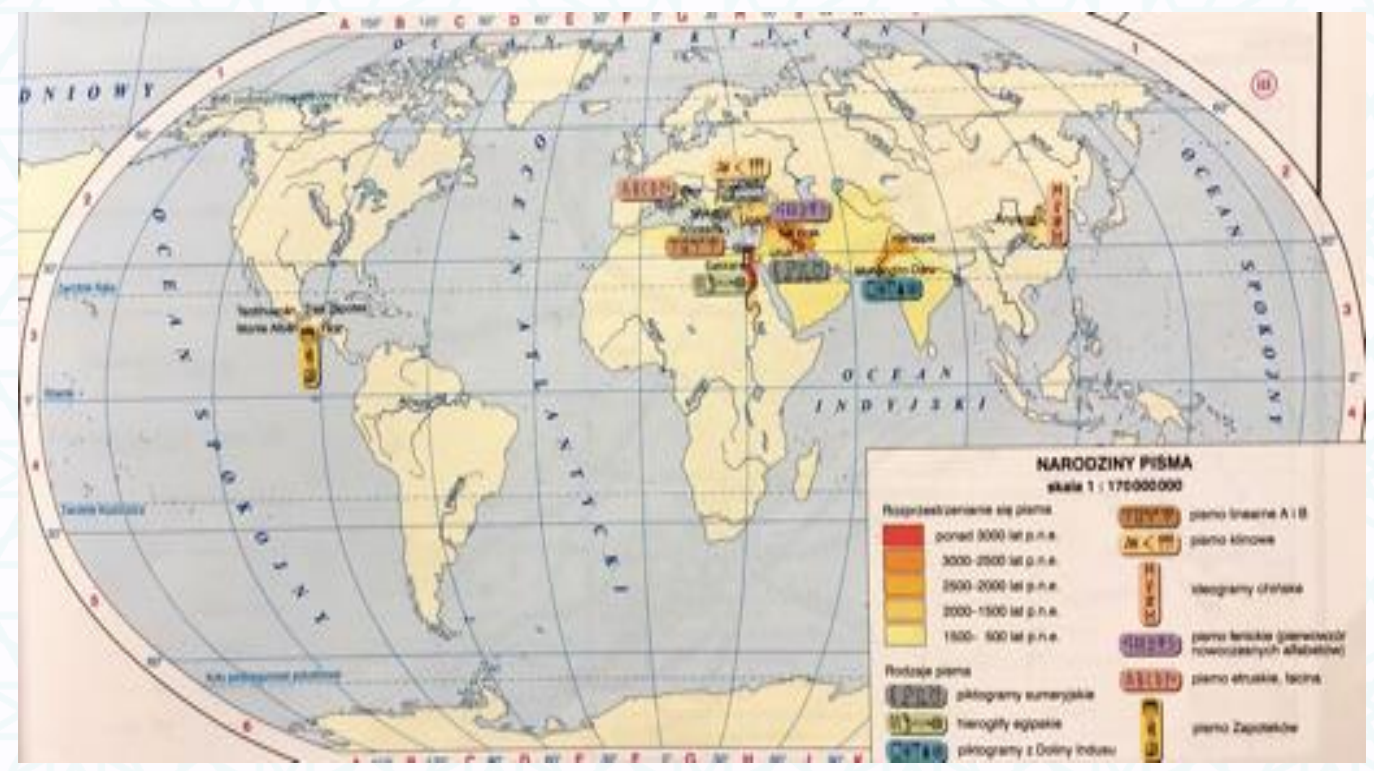

Lise düzeyinde hazırlanmış olan bu tarih atlasında yer alan Şekil 8, tüm yazı türleri, nerede ve ne zaman meydana geldikleri gibi bilgiler içermektedir. Atlas lise düzeyine hitap ettiğinden harita, lejant koordinat ve ölçek gibi özelliklere de sahiptir. Haritanın lejantı gayet anlaşılır olup sembollerde gereksiz simgeler ve bilgiler de bulunmamaktadır. Yazının Doğuşu adlı haritanın lejantı incelendiğinde ise renklerle yazı türlerinin yayılma alanları ve dönemleri dünya üzerinde gösterilmektedir. Sümer yazısı, Mısır hiyeroglifi, İndus vadisinde kullanılan yazı, Linear A ve B yazıları, Fenike yazısı, Latin yazısı gibi yazı türleri harita lejantında yer almaktadır.

\section{Dinler}

Tarih atlaslarında görülen din konulu haritalar kullanılan semboller açısından dikkat çekicidir. Cappelens Historiske Atlas (Norveç) adlı tarih atlasında günümüz dünyasında dinlerin yayıldığı alanlar gösterilmektedir (Şekil 9). Haritada lejant haricinde başka hiçbir harita özelliği bulunmasa da dinlerin Katolik, Ortodoks, Sünni, Şii gibi mezhep türlerini içermesi ve her dinin sembollerinin kullanılması haritayı ilgi çekici kılmaktadır. Tarih atlaslarında günümüz durumunun da görülmesi ayrıca düşünülmesi gereken farklı bir bakış açısıdır. Bu durumda her tarih atlasının güncel değişmeleri de takip ederek belirli dönemlerde kendini yenilemesi gerektiği fikri doğmaktadır. 
Şekil 9. Dünyada Dinler, Cappelens Historiske Atlas, Norveç (2004)

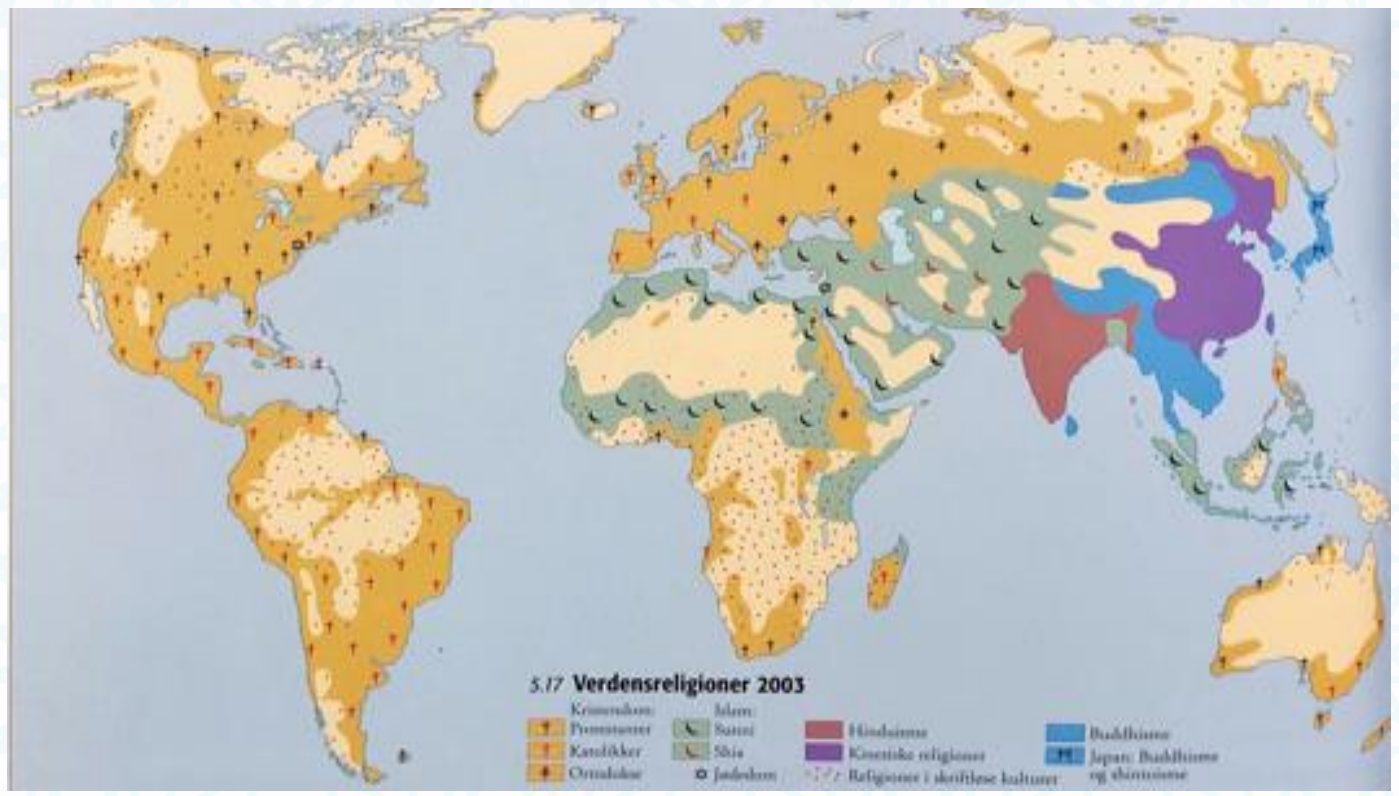

Dinler konusunda bir harita da Atlas Vicens Vives De Historia (İspanya)'dan verilebilir. Bu haritada 11-13.yüzyıllarda Hıristiyan dünyası (Şekil 10) sunulmuştur. Haritada Avrupa'da Katolik dünyası, Ortodoks dünyası ve İslam dünyası sunulurken, manastırlar, patrikhaneler ve piskoposluklar gösterilmiştir.

Şekil 10. Hıristiyanlık (XI-XIII. yüzyıllar), Atlas Vicens Vives De Historia, İspanya (2008)

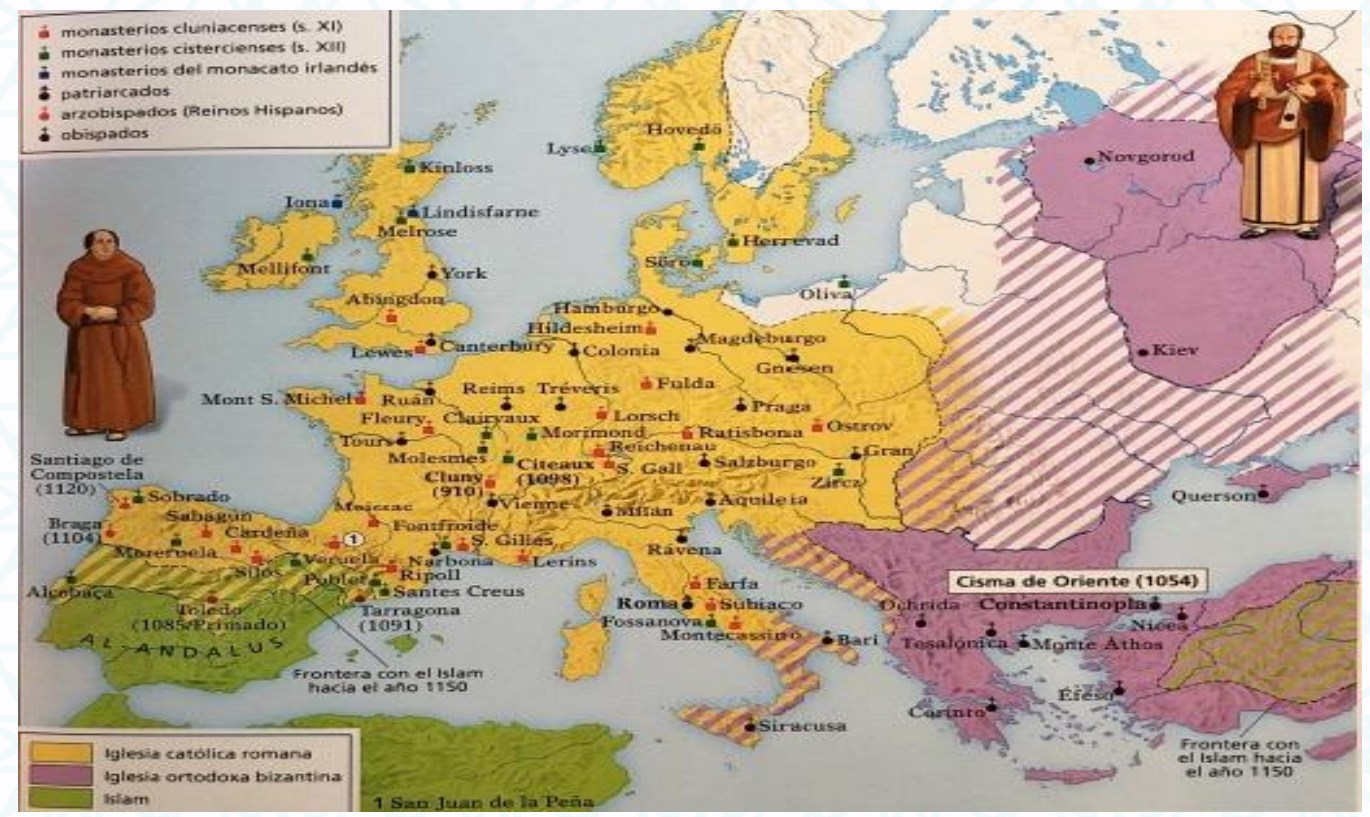

Atlante di storia (İtalya) tarih atlasında da 18.yüzyılda Avrupa coğrafyasında dinlerin yayılma alanlarını gösteren bir harita yer almaktadır. Harita hangi ülkelerde hangi dinler var şeklinde göstermemekte, bunun yerine bu yüzyılda Hristiyanlık dininin mezheplerinin yayılma alanlarını anlatmaktadır. Ayrıca bu haritada Anadolu (Batı Trakya hariç) ve Karadeniz'in kuzeyi de (Kırım yarımadası) Müslüman olarak gösterilmiştir: 
Şekil 11. 18.yüzyılda Avrupa'da Dini Mezhepler, Atlante di Storia, İtalya (2000)

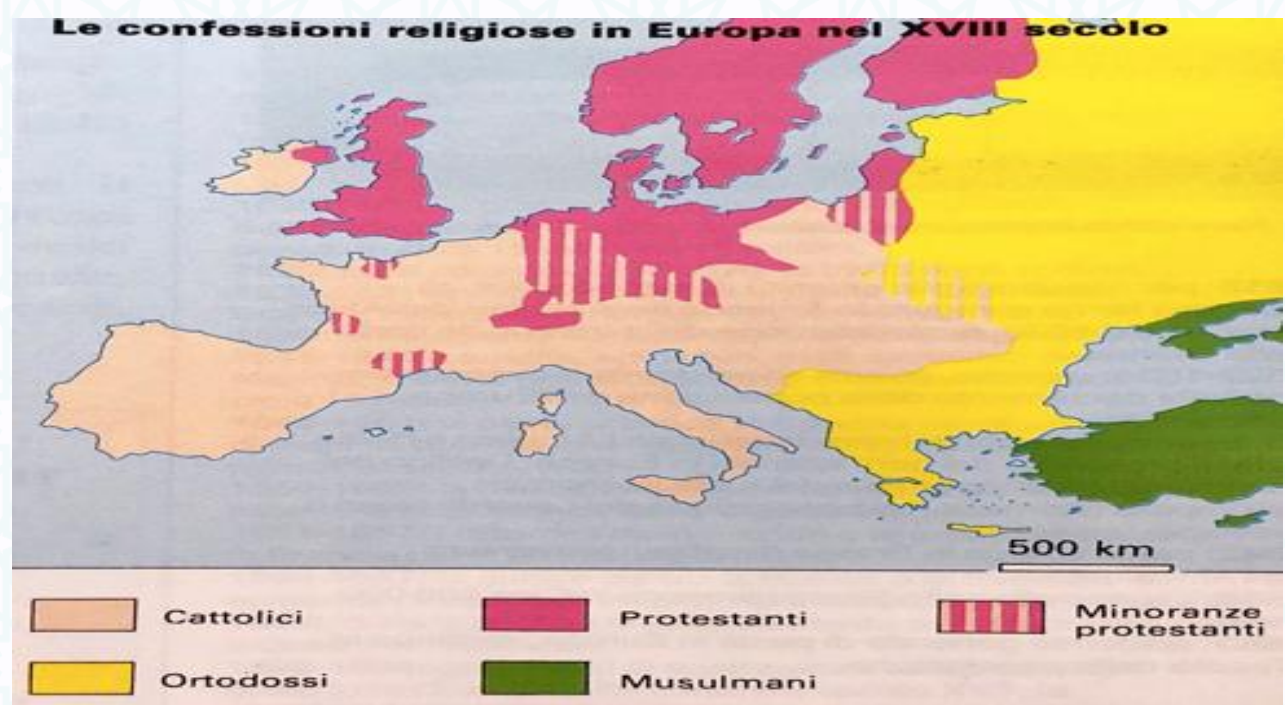

Középiskolai történelmi atlasz (Macaristan)'da ise 7. ve 13. yüzyıllarda İslam kültürünün yayılma alanını anlatan bir harita yer almaktadır. Bu haritada lejantın yanı sıra edebiyat felsefe, matematik ve coğrafya gibi alanlarda yetişmiş birçok alimin adları verilmiş (el-Kindî, el-Farabî, Harezmî, Tebarî gibi), İslam kültürünü oluşturan temel unsurlar ve örnekler sunulmuştur. Sadece bu haritanın incelenmesi ile 7.-13.yüzyılarda İslam dünyasında önde gelen tüm unsurlar hakkında bilgi sahibi olunabilir:

Şekil 12. Arap ve İslam Kültür Dünyası (VII-XIII. yüzyıllar), Középiskolai Történelmi Atlasz, Macaristan (1998).

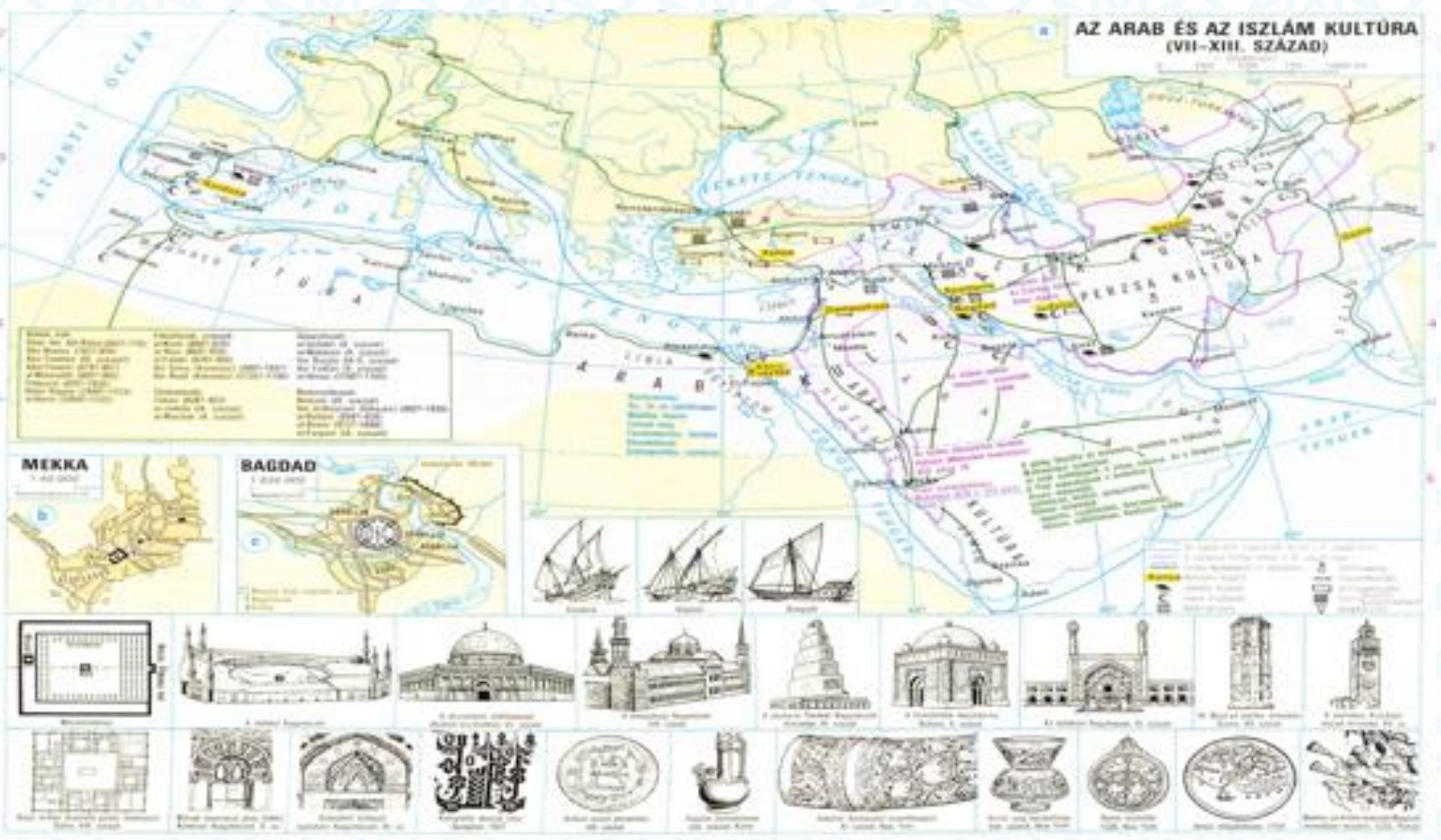




\section{Bilimsel ve Teknolojik Gelişmeler}

Tarih atlaslarında dönemin filozof ve bilim adamları, bilimsel faaliyetler, üniversiteler, teknik gelişmeler gibi konular da harita olarak sunulmuştur. Viduramžiai: Atlasas Konspektas Žodynas (Litvanya)'da yer alan üniversiteler haritası (Harita 9), 11.-17.yüzyıllar arasında Avrupa'da kurulan üniversiteleri göstermektedir:

Şekil 13. Orta Çağ’daki Üniversiteler, Viduramžiai: Atlasas Konspektas Žodynas, Litvanya (2010)

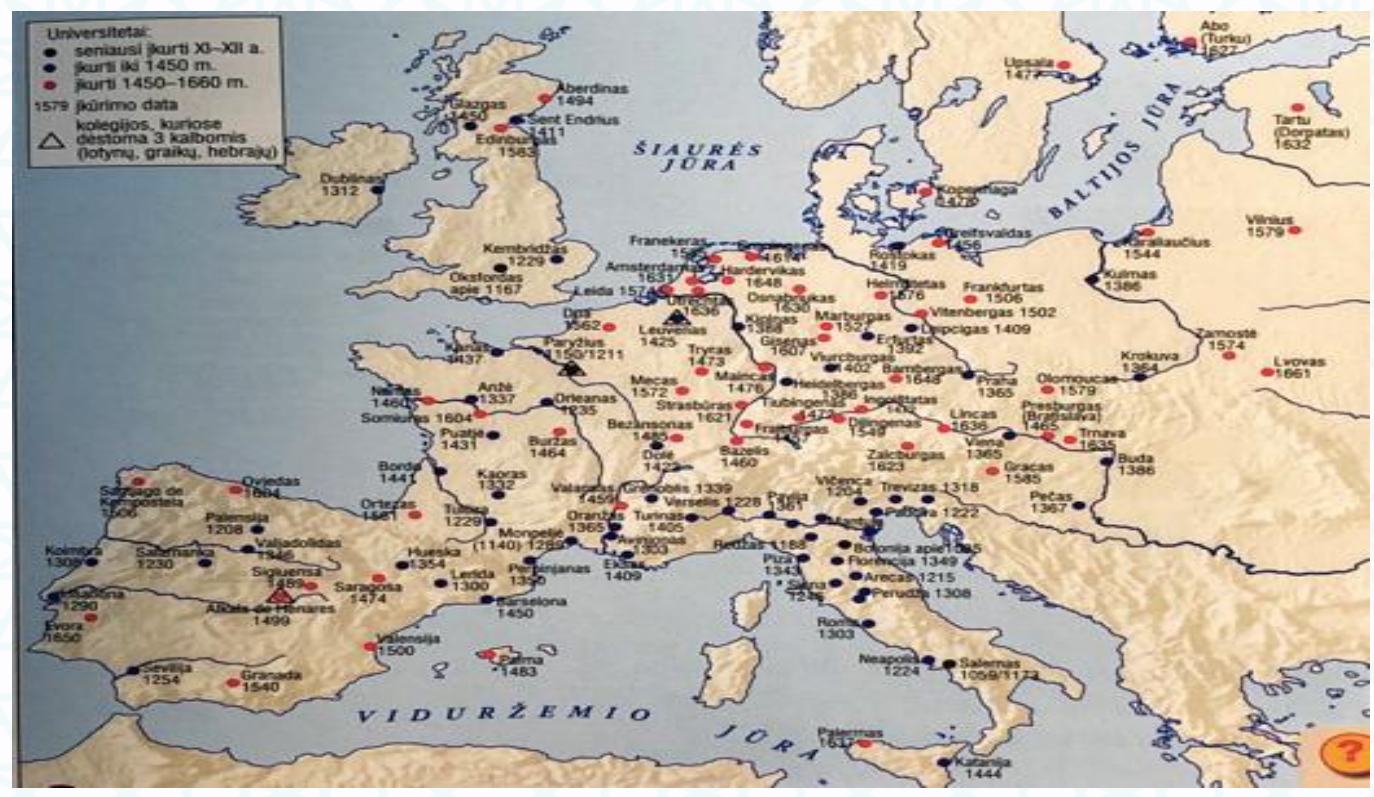

Şekil 13'te 11.yüzyıldan itibaren Orta Çağ'da Avrupa'da kurulmuş üniversiteler gösterilmiştir. Üniversiteler kuruluş dönemlerine göre de farklı renklerle temsil edilmiştir. Ortaöğretim düzeyindeki Atlas Historique (Fransa)'de Avrupa'nın Işıkları başlıklı haritada (Şekil 14), Avrupa'da o dönemdeki üniversite, büyük akademi merkezleri, büyük bilim ve felsefe yayın merkezleri, astronomi gözlem evleri ve Versay Sarayı modelinde tasarlanmış saraylar gösterilmektedir:

Şekil 14. Avrupa'nın Işıkları, Atlas Historique, Fransa (2000)

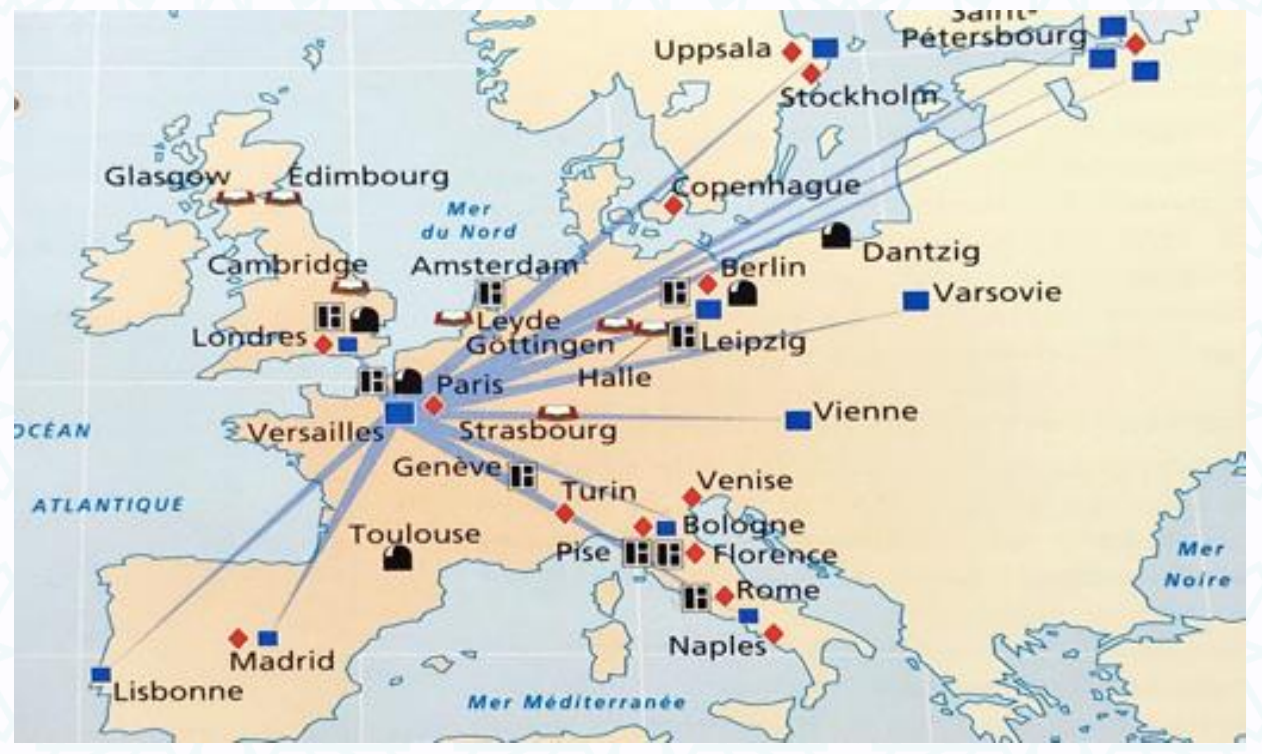


Képes történelmi atlasz (Macaristan)'da ise 15.-18. yüzyıllarda Avrupa'daki bilim ve sanat alanındaki gelişmeler konu edilmiş, bu dönemin önemli bilim insanları, sanatçıları ve eserler haritada (Şekil 15) yer almıştır:

Şekil 15. Avrupa'da Bilim ve Sanat, Képes Történelmi Atlasz, Macaristan (2001)

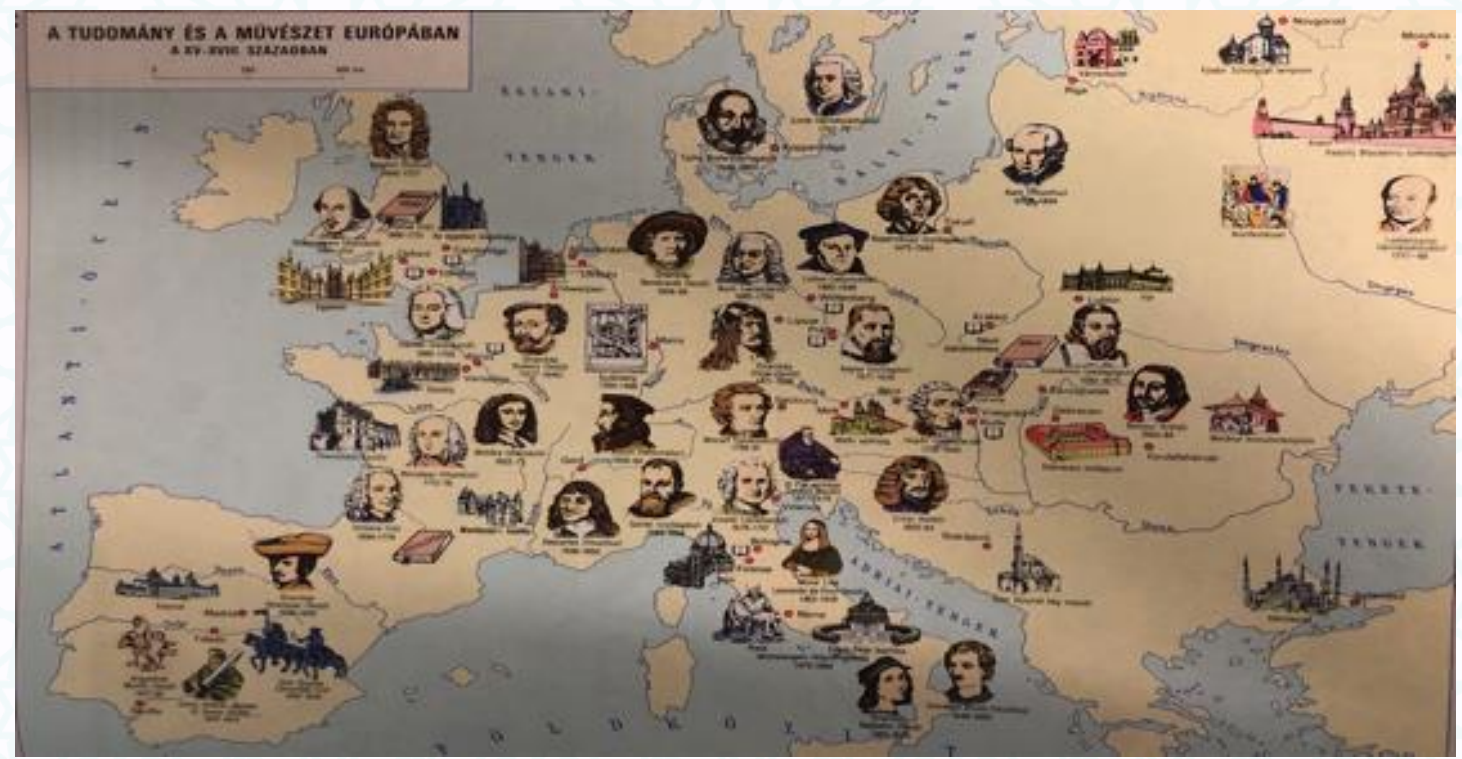

Şekil 15; konum, ölçek, yön ve lejant gibi harita özelliklerinden herhangi birine sahip değildir. Haritanın sadece adı vardır. Ancak sunulan görsel öğeler dikkat çekicidir. Özellikle dönemin önde gelen bilim ve sanat insanlarının görsellerinin verilmesi haritayı farklı kılmaktadır. Canlandırılan kişiler ve bu kişilerin yaşadıkları yerlerin gösterilmesi ayrı bir harita okumasında hangi ülkede hangi bilim insanı ya da sanatçının olduğunu sunması açısından da önemlidir. Buna benzer bir harita da Atlas Historyczny (Polonya)'de bulunmaktadır. Bu harita (Şekil 16) Rönesans dönemi gelişmelerini anlatmaktadır. Haritanın lejantından anlaşıldığı üzere Hümanizm merkezleri, Rönesans döneminde kurulan üniversiteler, seçilmiş Rönesans anıtları, kutsal yerler, kaleler ve saraylar, çeşitli Rönesans anıtları temsil edilmiştir. Harita lejant, ölçek, konum özelliklerini taşıması yönünden de dikkat çekicidir:

Şekil 16. Avrupa Rönesans'ı, Atlas Historyczny, Polonya (2009)

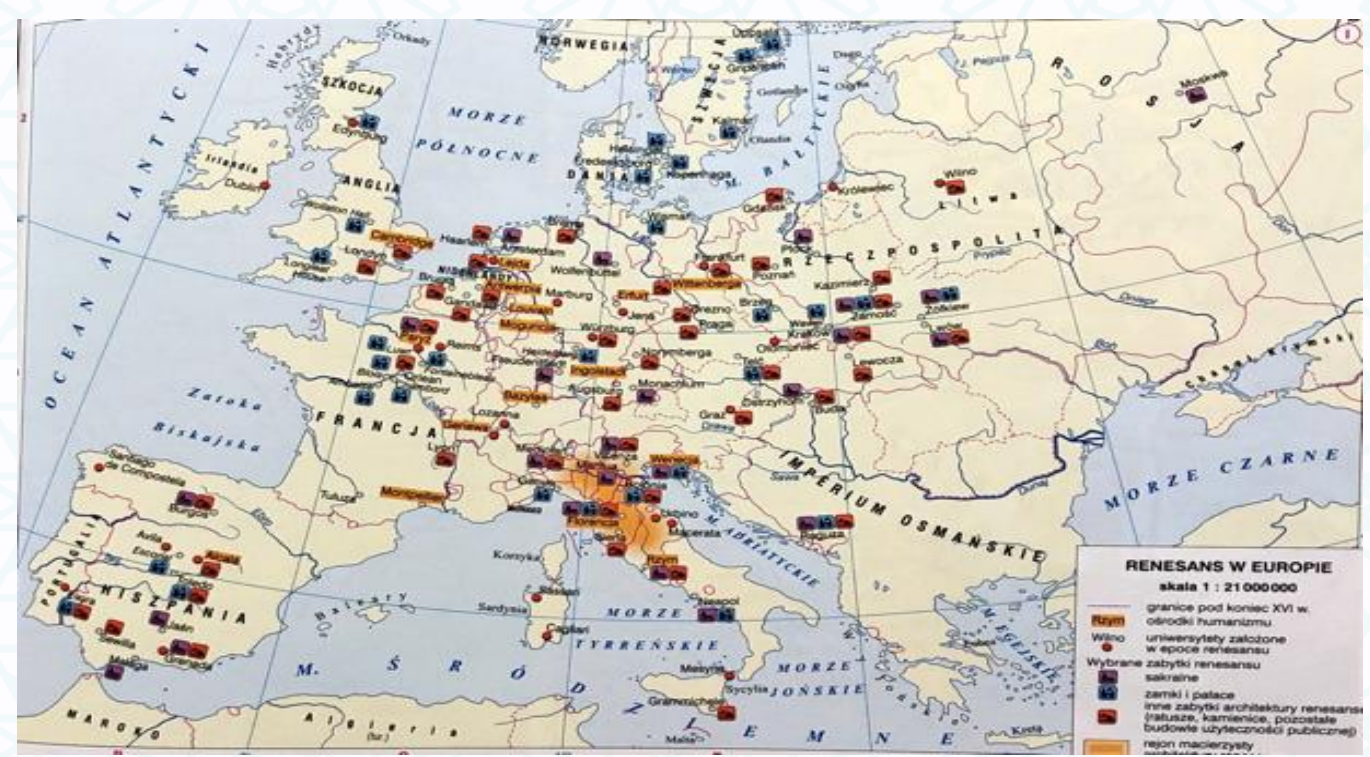


Tarih atlaslarında teknolojik gelişmeler hakkında da haritalar bulunur. Képes történelmi atlasz (Macaristan)'da 19.yüzyıldan günümüze teknolojik gelişmeleri gösteren harita (Şekil 17) şu şekildedir:

Şekil 17. Avrupa'da Teknoloji Alanında Büyük Gelişmeler, Képes Történelmi Atlasz, Macaristan (2001)

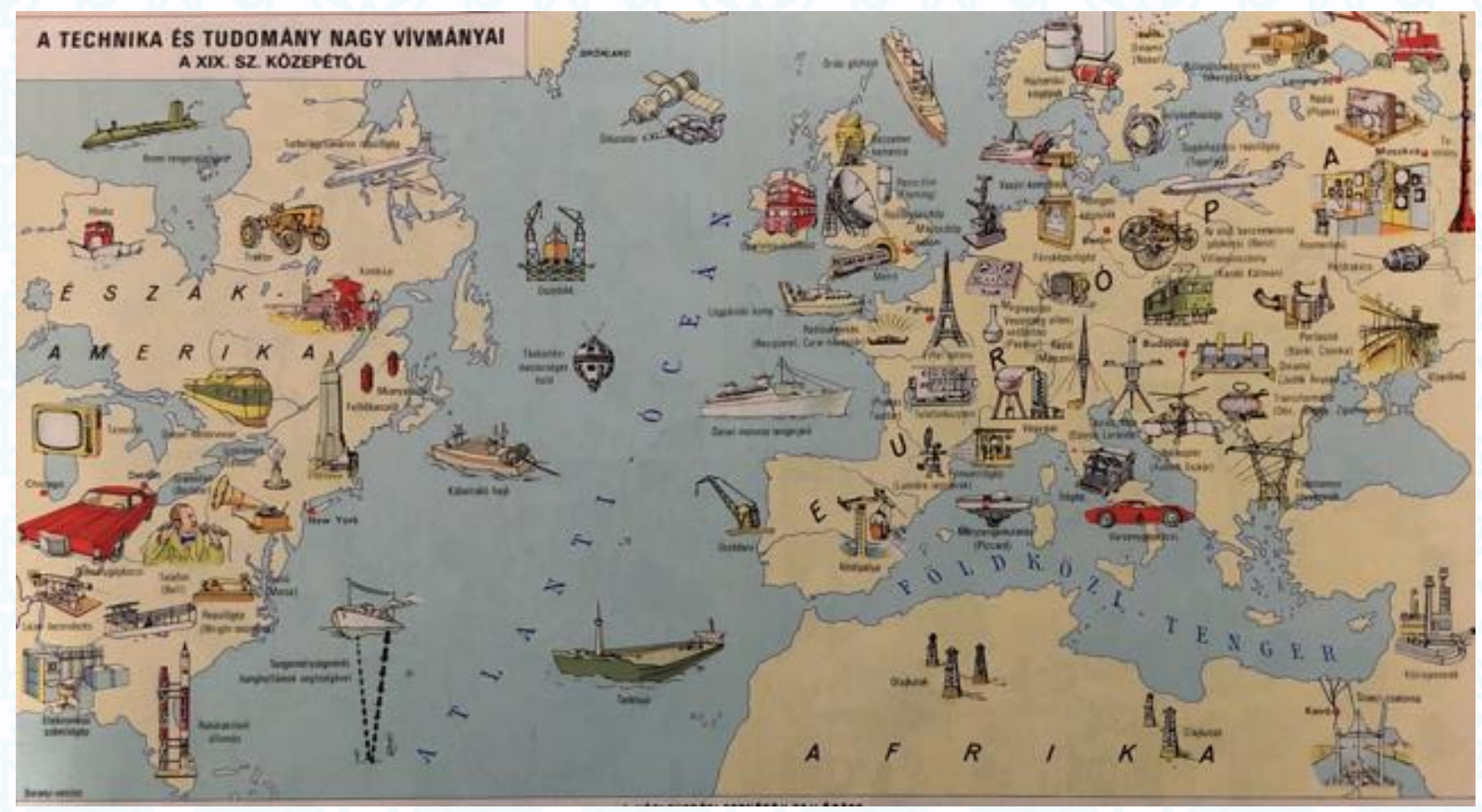

Şekil 17'de, 19.yüzyıldan günümüze Avrupa ve Amerika kıtasında teknik alanda yaşanan gelişmeler sunulmuştur. Harita incelendiğinde otomobilden televizyona, uçaktan gemilere, elektrik santrallerinden bilim ve sağlık alanındaki ürünler ve yeniliklere kadar birçok gelişme haritaya canlandırmalarla birlikte konu edilmiştir. Haritanın hemen altında ulaşım araçlarının değişimini yıllara göre sunan bir görsel bulunmaktadır:

Şekil 18. Ulaşım Araçlarının Gelişimi, Képes Történelmi Atlasz, Macaristan (2001)

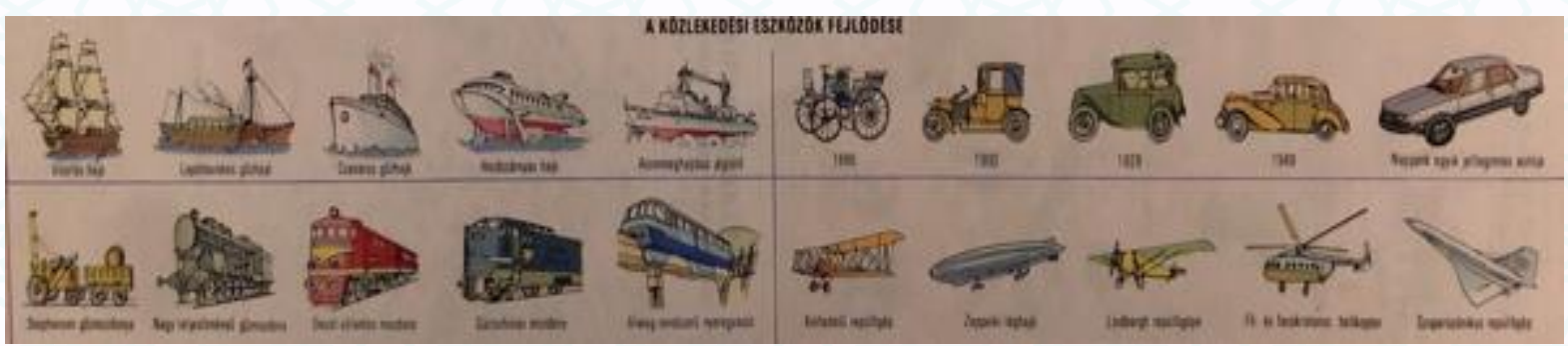

Şekil 18, öğrencinin değişim ve sürekliliği görebilmesi ve anlamlandırabilmesi açısından oldukça dikkat çekicidir. Şekil 18, bir konu üzerinde yıllara bağlı olarak taşıt türlerinin çeşitliliğinin artması ve taşıtların değişimi hakkında oldukça geniş bilgi içermektedir.

\section{Beşerî Faaliyetler}

Tarım, hayvancılık, ticaret gibi günlük faaliyetler de atlaslarda harita olarak sunulabilmektedir. ИСТОРИЈСКИ АТЛАС (Sırbistan)'da ilkçağda yapılan faaliyetler gösterilmektedir (Şekil 19). Şekil 19'un lejantından da anlaşılacağı üzere yapılan tarım ve hayvancılık faaliyetleri ve bilimsel merkezler de haritalara konu olabilmektedir: 
Şekil 19. İlk Çağ’da Yapılan Faaliyetler, ИСТОРИЈСКИ АТЛАС, Sırbistan (2008)

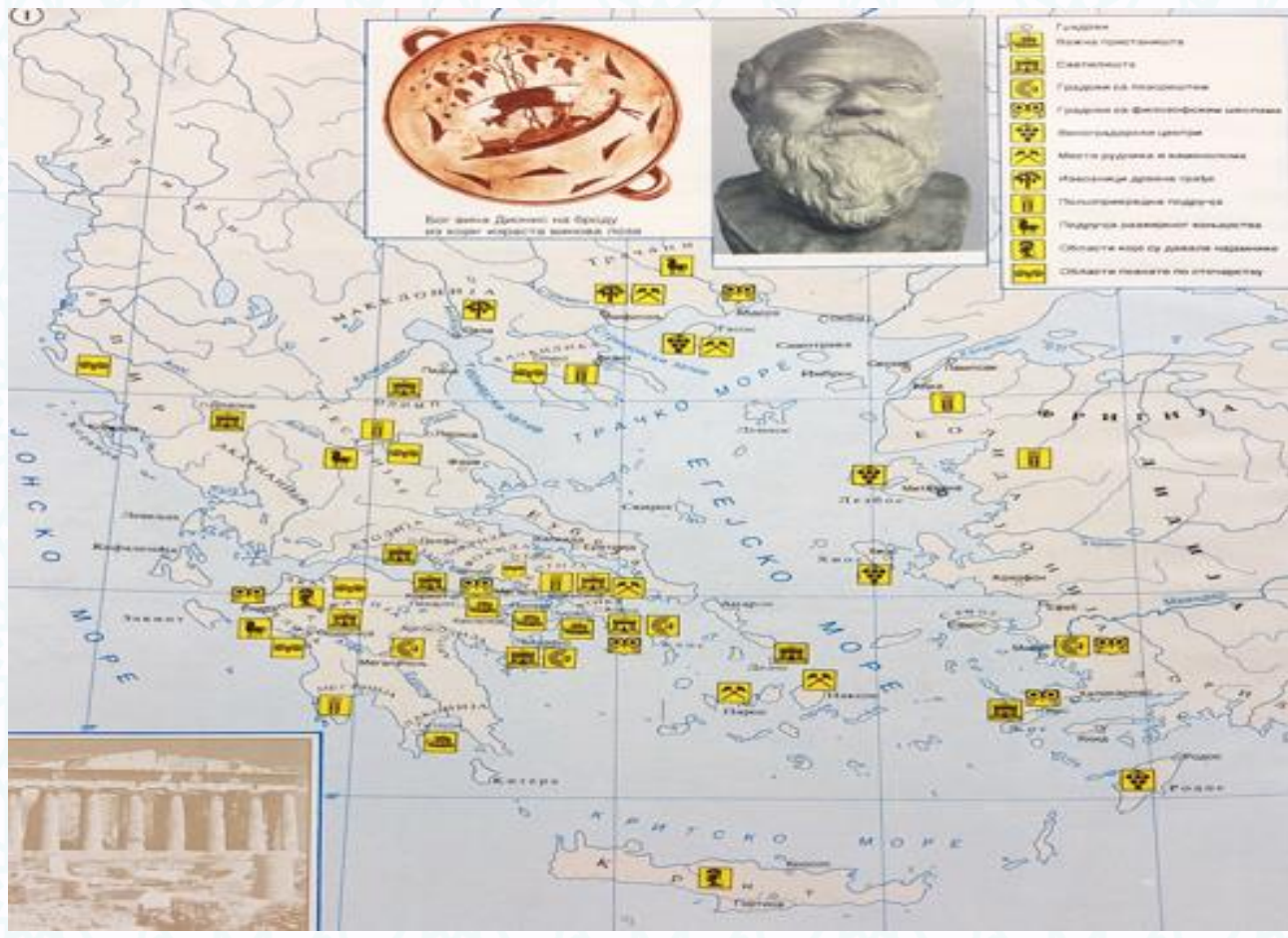

Spotkania z historią (Polonya) lise tarih atlasında dünyada tarım faaliyetlerinin başlangıcını gösteren bir harita (Şekil 20) bulunmaktadır:

Şekil 20. Tarımın Başlangıcı (M.Ö. 9000’den 3000'e), Spotkania z Historią, Polonya (2007)

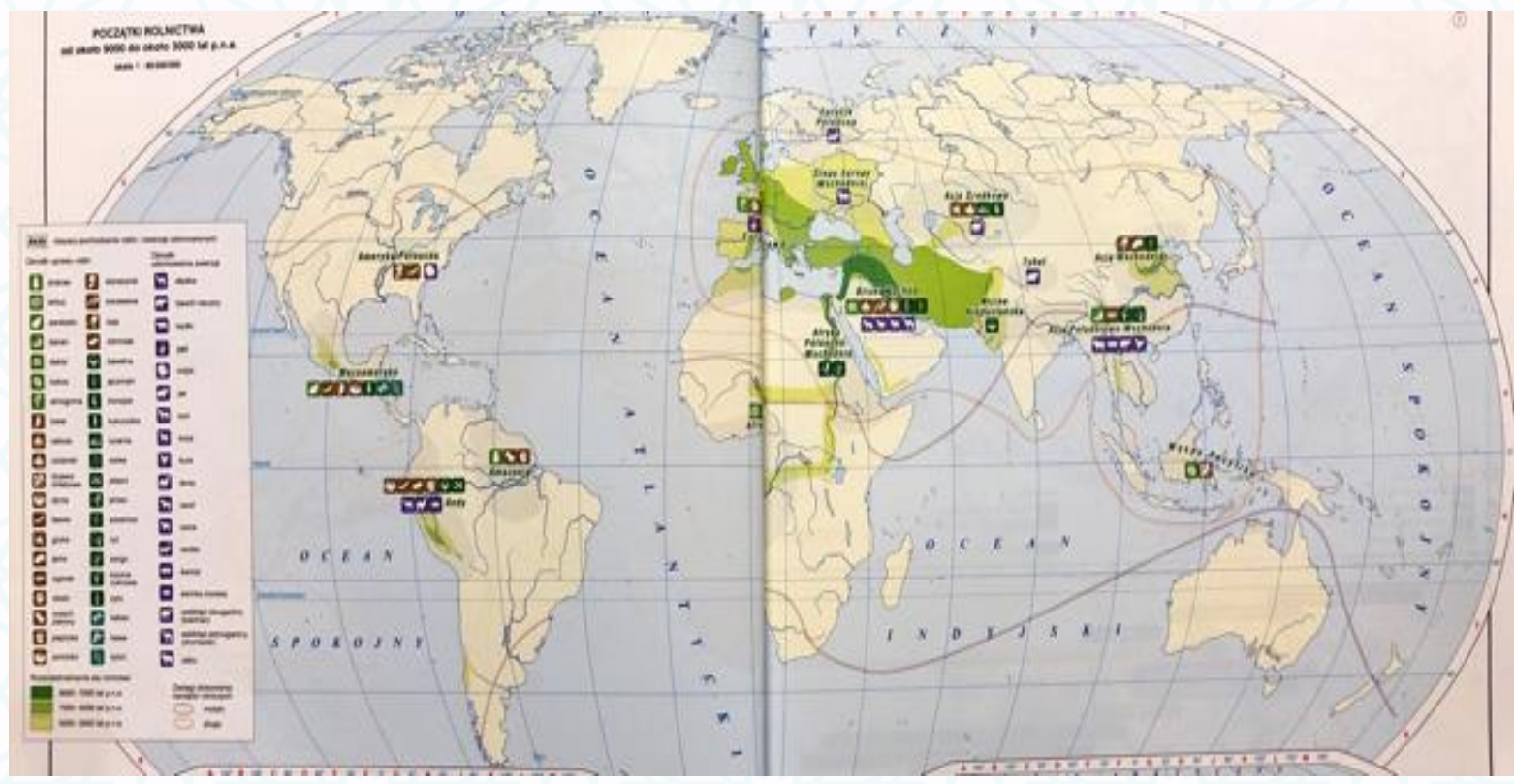

Şekil 20'de M.Ö.9000-M.Ö.3000 yılları arasında dünyada tarımsal faaliyetlerin başlangıcı gösterilmektedir. Haritada tarım faaliyetlerinin tüm dünya üzerinde gösterilmiş olması öğrencinin bu dönem aralığında nerelerde yaşam alanlarının olduğunu görmesi açısından da önemlidir. Haritanın lejantı oldukça dikkat çekicidir. Harita lejantında yer alan tarım ürünleri ve hayvan türleri o dönemlerde yapılan beşerî faaliyetlerin genel bir özeti niteliğindedir. 
Lise düzeyinde hazırlanmış olan bu tarih atlasında Yunan Kolonizasyonları (Şekil 21) adlı haritanın lejantı bitkilerin ve evcil hayvanların menşeilerini ve yaşam alanlarını göstermektedir. Lejant incelendiğinde okura farklı fikirler ve görüşler sunduğu anlaşılmaktadır. Harita, hitap ettiği sınıf düzeyine göre de harita özelliklerine (yön hariç) sahiptir.

Şekil 21. Yunan Kolonizasyonları, Spotkania z Historia, Polonya (2007)

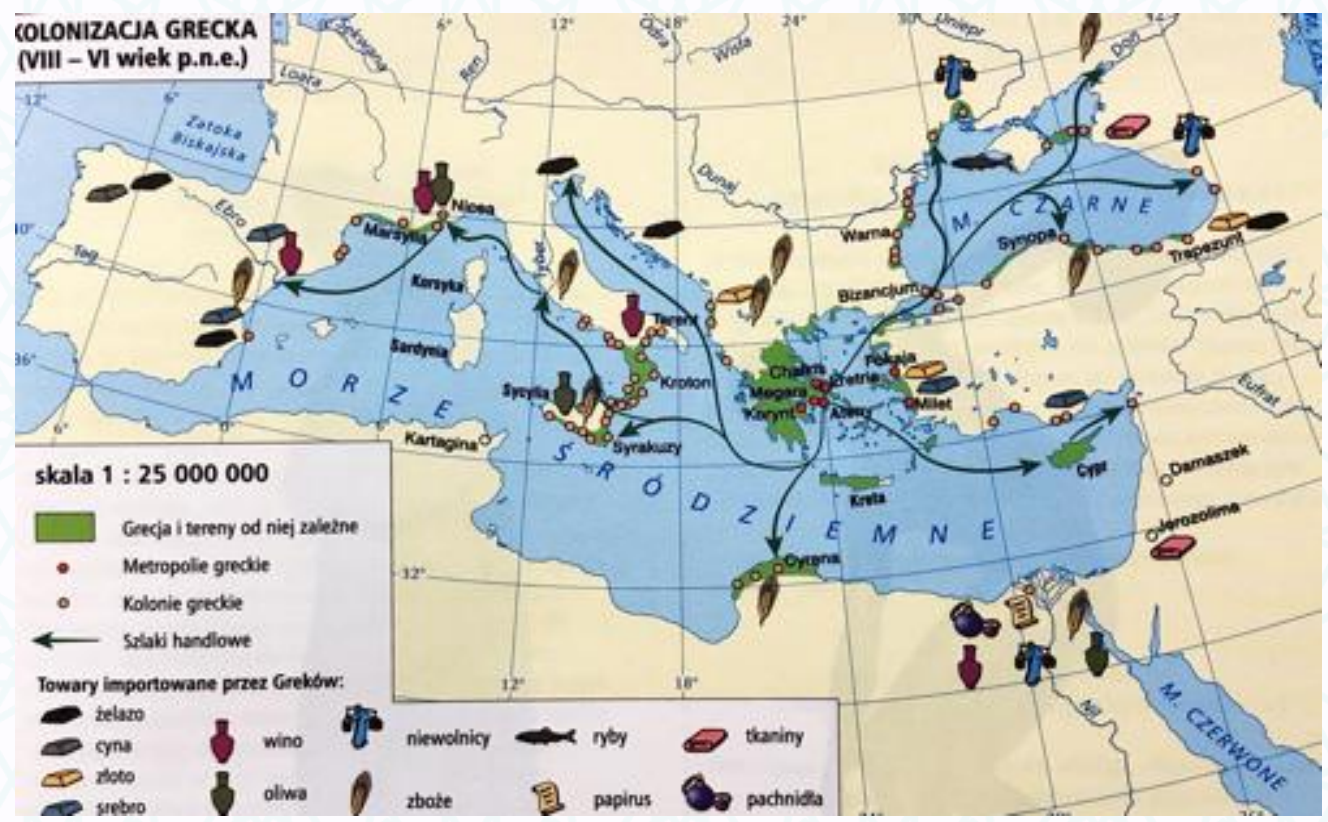

Képes történelmi atlasz (Macaristan)'da ise günümüz beşerî faaliyetleri sunulmuştur (Şekil 22). Haritada kullanılan resimler/sembollerle tüm dünyada kıtalar üzerinde yapılan ticaret, balıkçılık, teknoloji, endüstri, tarım gibi faaliyetler anlatılmaktadır. Harita tüm faaliyetleri lejant kullanmaksızın canlandırmalarla sunmaktadır:

Şekil 22. Günümüz Hayatı, Képes Történelmi Atlasz, Macaristan (2001)

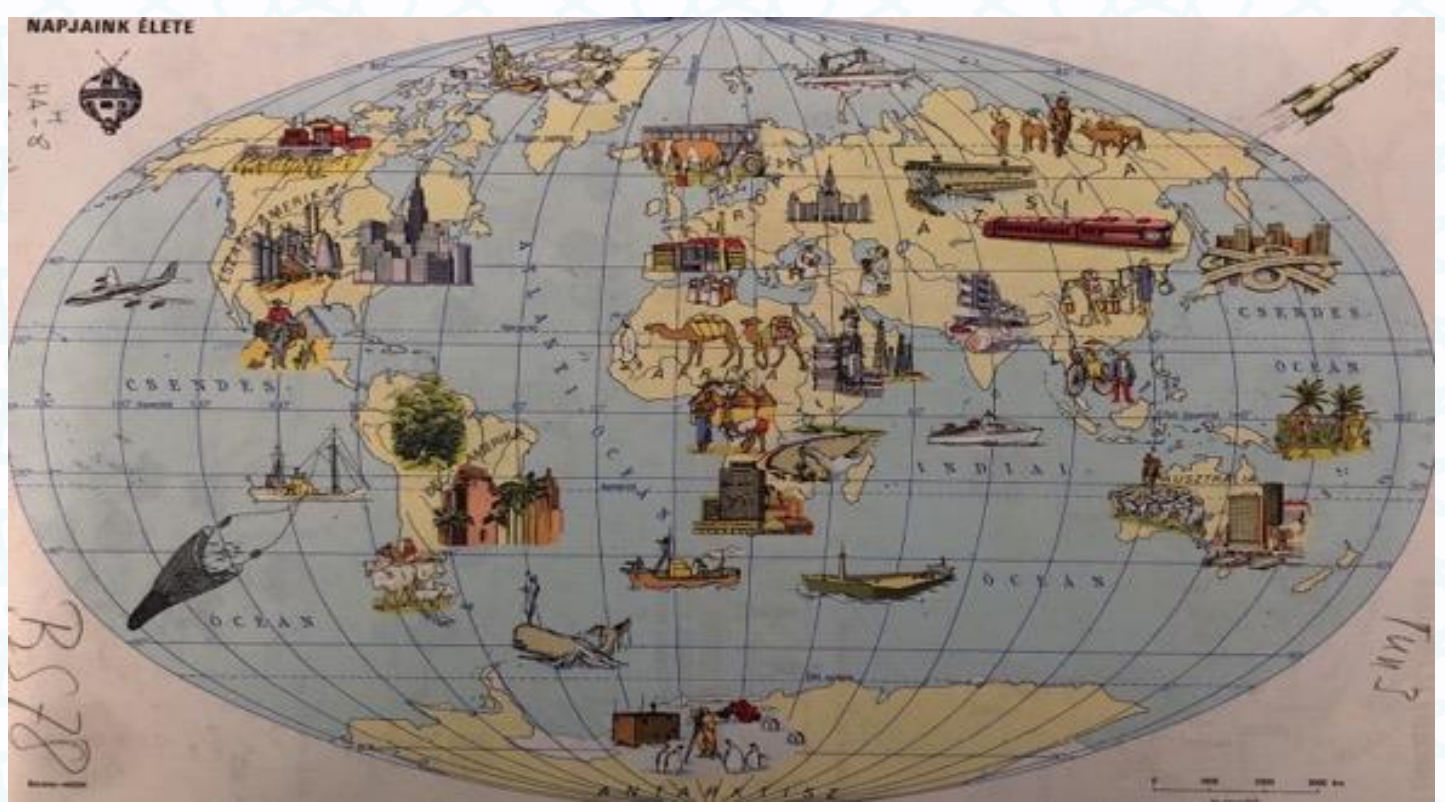

\section{Salgın Hastalıklar}


Tarih atlaslarında dünyada etkili olmuş salgın hastalıklar ile ilgili de haritalar bulunmaktadır. Putzger Historischer Weltatlas (İsviçre)'da Avrupa'da 1829-1837 tarihlerinde etkili olan kolera salgını anlatılmaktadır (Şekil 23). Atlas lise ve üst düzey öğretime hitap ettiğinden haritada ölçek, lejant, yön ve koordinat gibi tüm harita özelliklerini de barındırmaktadır:

Şekil 23. Avrupa'da Kolera 1829-1837, Putzger Historischer Weltatlas, İsviçre (2004)

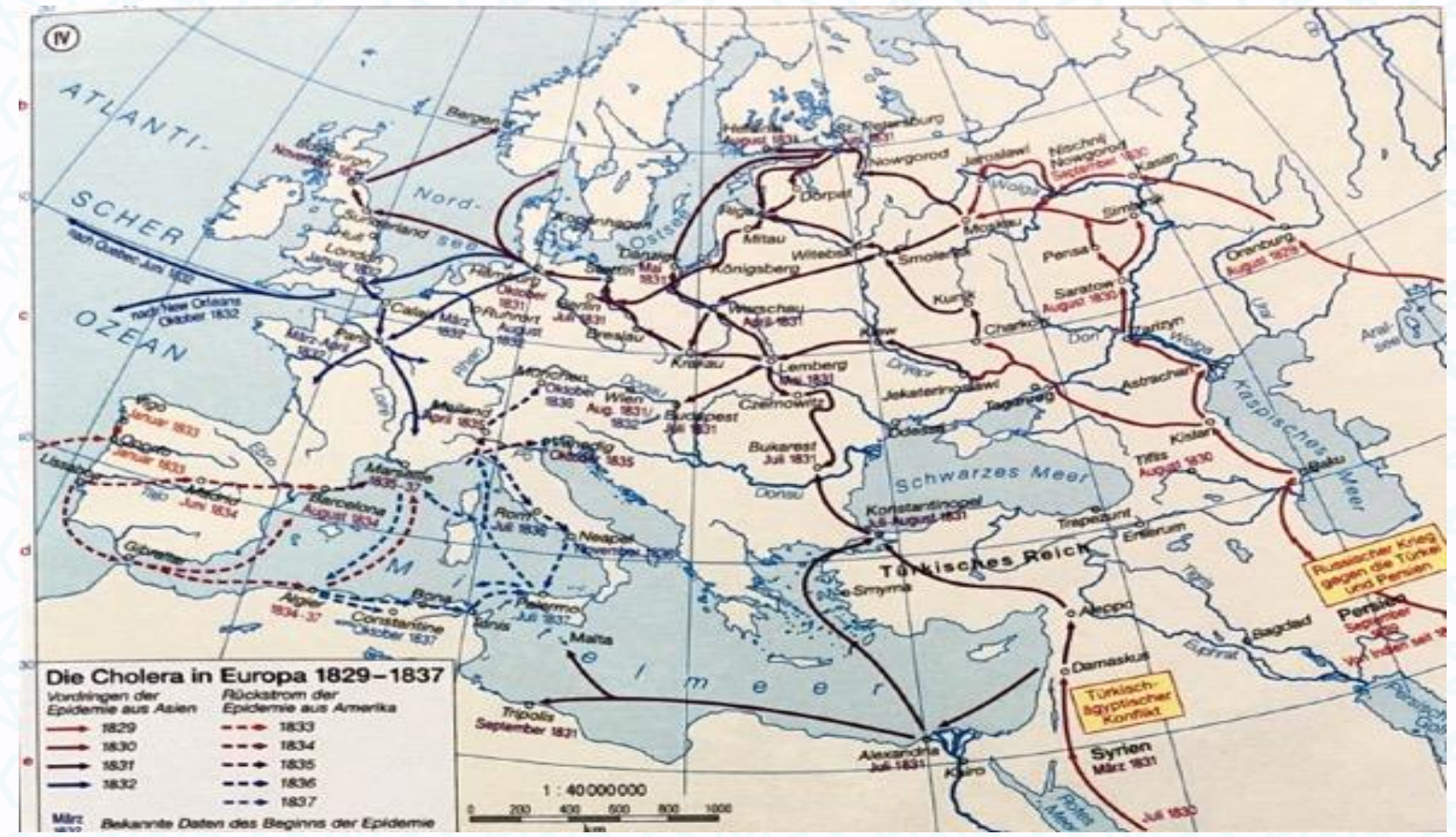

Şekil 23'te yer alan haritanın lejantına göre düz çizgiler salgının Asya üzerinden gelen nüfuzunu, kesik çizgiler ise koleranın Amerika'dan gelen nüfuzunu göstermektedir. Çizgilerde kullanılan renkler yıllara göre kullanılmıştır. Aynı tarih atlasında 1918 yılında Avrupa'da etkili olan "ispanyol Gribi” salgını da konu edilmiştir (Şekil 24). Haritanın lejantında Nisan 1918Temmuz 1918 aralığında gribin yayılma alanları farklı renkler kullanarak anlatılmış; ayrıca Ağustos/Eylül 1918 döneminde ikinci bir salgının yaşandığı ve daha çok etkilenenler olduğu da belirtilmiştir:

Şekil 24. Avrupa'da İnfluenza 1918, Putzger Historischer Weltatlas, İsviçre (2004)

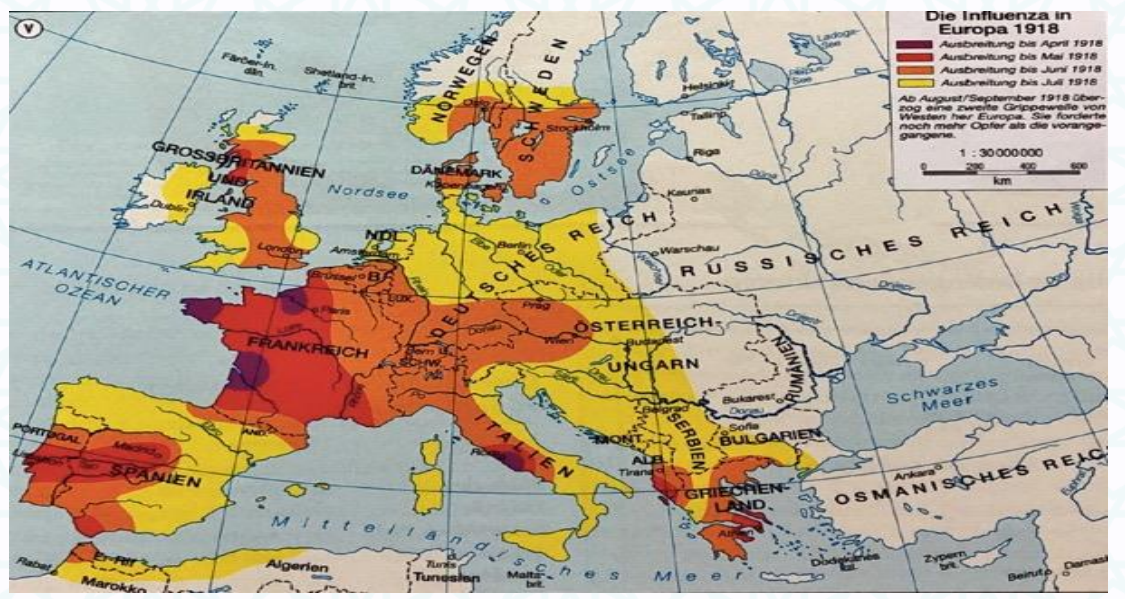


Putzger Historischer Weltatlas Kartenauzgabe (İsviçre, 2012) tarih atlası, 21.yüzyılın Başında Salgın Hastalıklar (Şekil 25-26) başlığıyla 21. yüzyıl başlarında yaşanan salgın hastalıkları konu edinilmiş ve bu konu çerçevesinde günümüzde AIDS, Tüberküloz ve Sıtma ve Kolera salgınlarını ve yayılma alanlarını gösteren haritaları okura sunmuştur:

Şekil 25. 1980'lerin Başından Günümüze AIDS, Putzger Historischer Weltatlas Kartenauzgabe, İsviçre (2012)

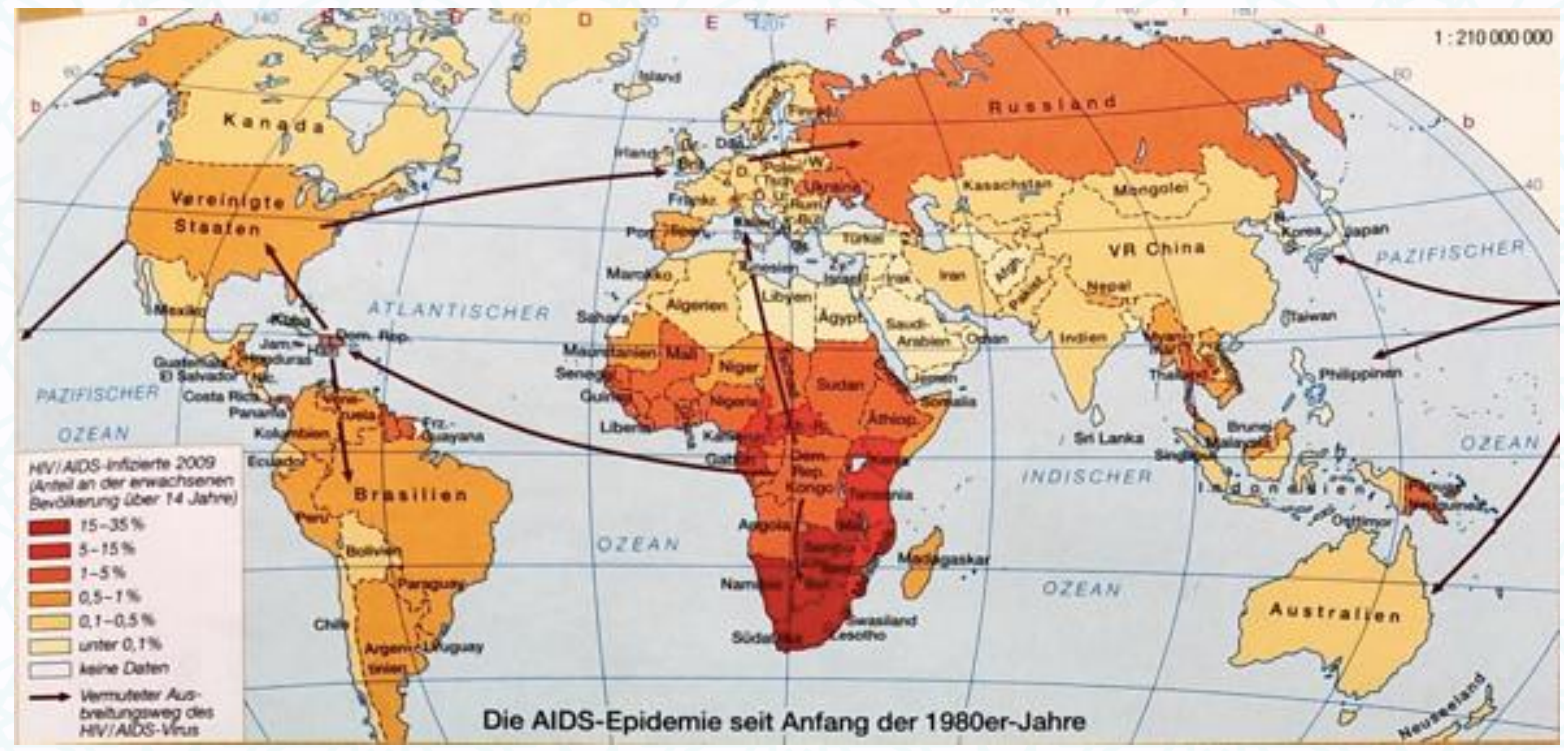

Şekil 25'te yer alan haritada AIDS salgını ele alınmış ve 1980 'lerin başından günümüze (2009'a) kadar dünyada yayılışı sunulmuştur. Şekil $26^{\prime}$ daki haritada ise Tüberküloz ve Sıtmanın yayılma alanları 2009'a kadar gösterilmektedir:

Şekil 26. Günümüzde Tüberküloz ve Sıtmanın Yayılması, Putzger Historischer Weltatlas Kartenauzgabe, İsviçre (2012)

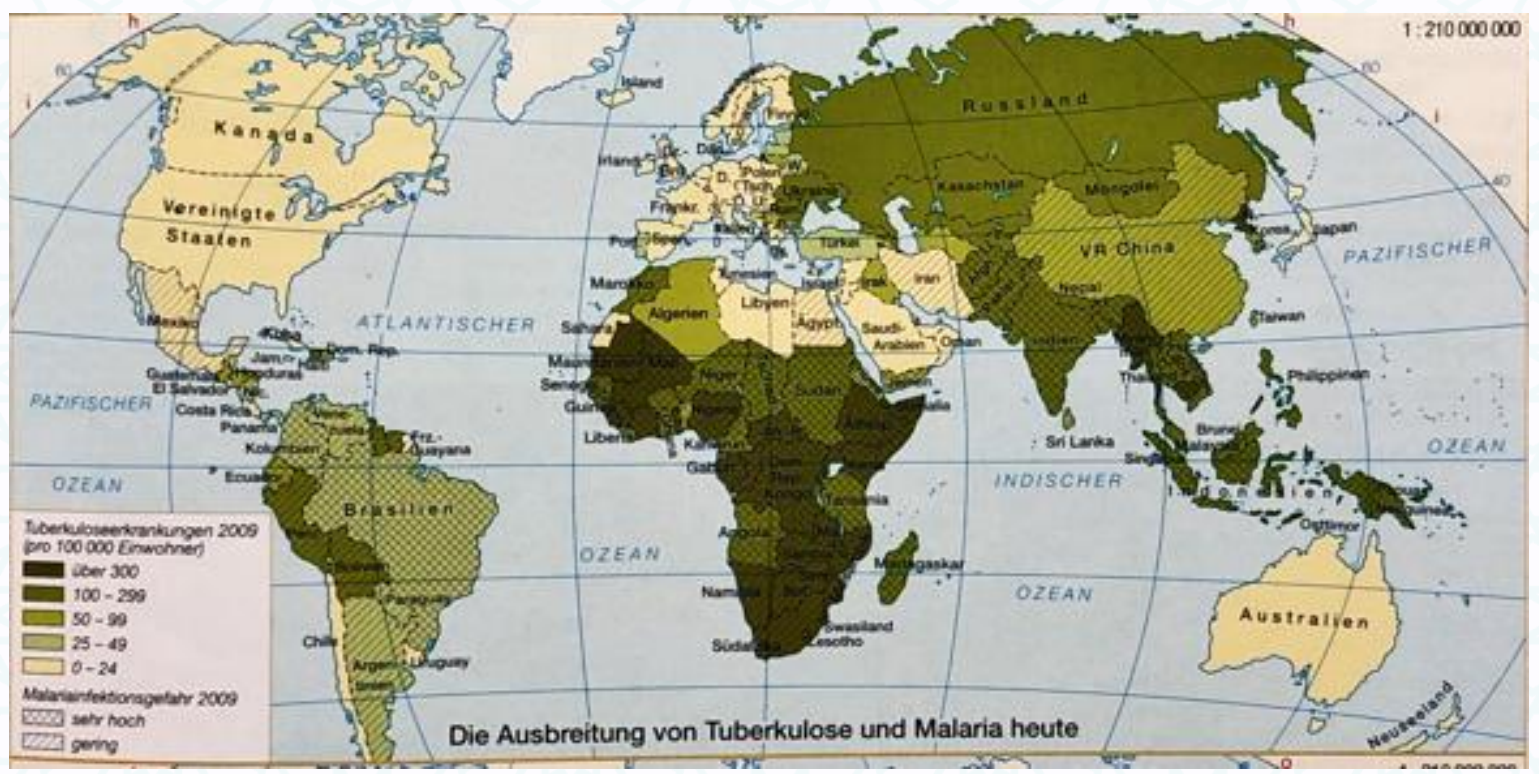




\section{Uluslararası Örgütler}

Tarih atlaslarında uluslararası örgütler ve bu örgütlerin faaliyet alanları ile ilgili haritalar da bulunmaktadır. Bosatlas Van De Geschiedeniscanon (Hollanda)'da Avrupa Birliği ve zaman içinde birliğe katılan ülkeleri gösteren harita (Şekil 27) bulunmaktadır. Oldukça uzun bir lejanta sahip olan haritada 1957 'den itibaren birliğe katılan ülkeler renklere göre gösterilmektedir. Ayrıca "Eurolanden" başlığı ile avro bölgesine katılan alanlar ve "Schengenlanden" başlığı ile Şengen vizesi uygulanan alanlar da gösterilmektedir. Birliğe ait parlamento, yüksek mahkeme, banka gibi kurumlar da haritada yer almaktadır:

Şekil 27. Avrupa Birliği, Bosatlas Van De Geschiedeniscanon, Hollanda (2008)

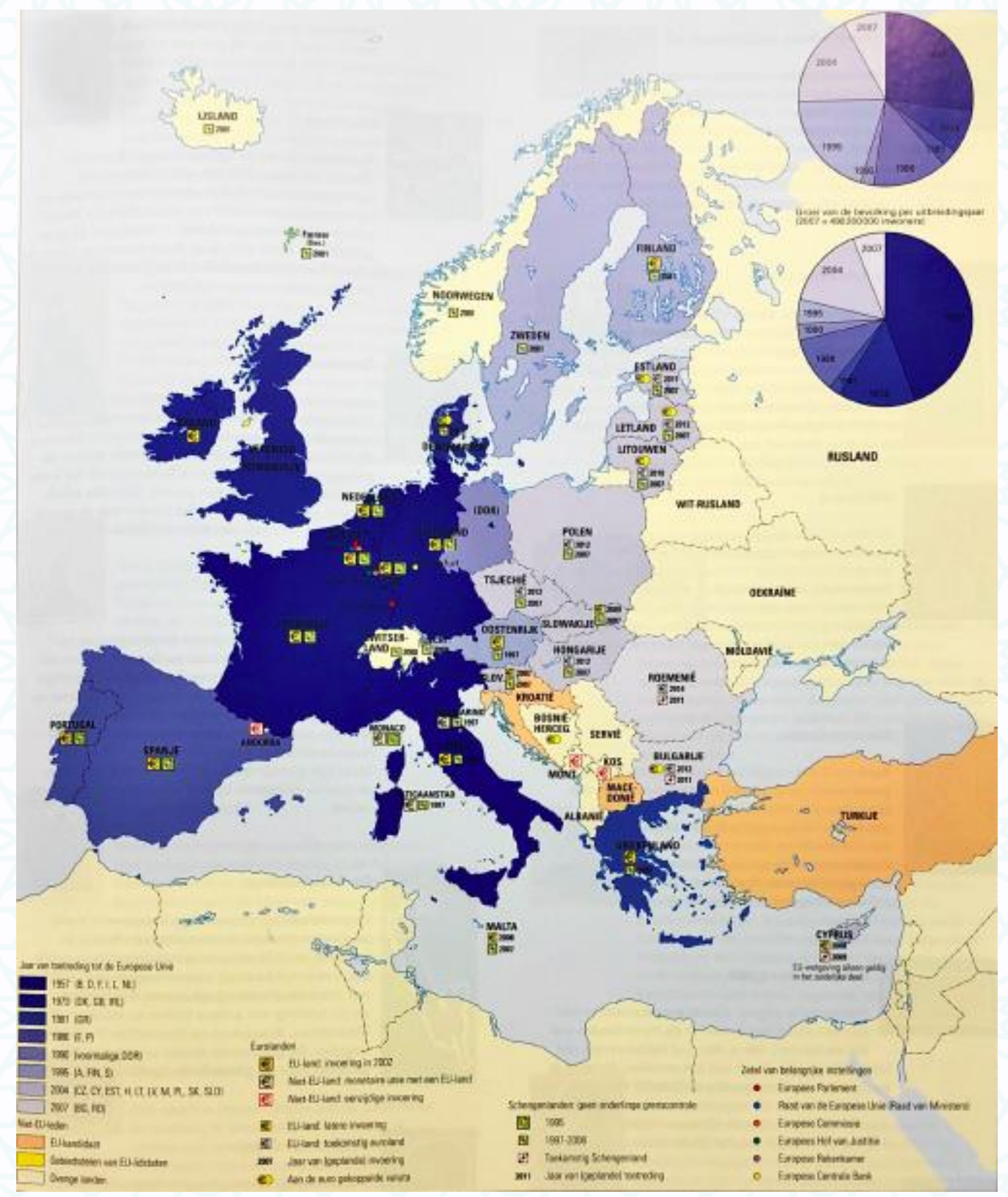

Avrupa Birliği haritasının (Şekil 27) lejantı Avrupa Birliğinin gelişimi sürecinin özeti gibidir. Zamana göre büyüyen birliğin genişlediği her dönem lejantta yer bulmuştur. Sadece bu lejanttan hareketle bile okura oldukça ayrıntılı bilgi verilebilmektedir. Haritanın hemen altında da Avrupa Birliğinin avroya geçişi tarih şeridi olarak verilmiştir. 
Putzger Historischer Weltatlas Kartenauzgabe (İsviçre), tarih atlasında ise Uluslararası Örgütler ve Dünya Krizleri adıyla verilen haritada (Şekil 28) Birleşmiş Milletler Örgütü, kurucu üyeler, 1945 'ten itibaren kayıt olan diğer ülkeler, dünya siyasetinde sorun çıkan alanlar ve Birleşmiş Milletlerin müdahale ettiği yerler haritaya konu edilmiştir:

Şekil 28. Uluslararası Örgütler ve Dünya Krizleri, Putzger Historischer Weltatlas Kartenauzgabe, İsviçre (2012)

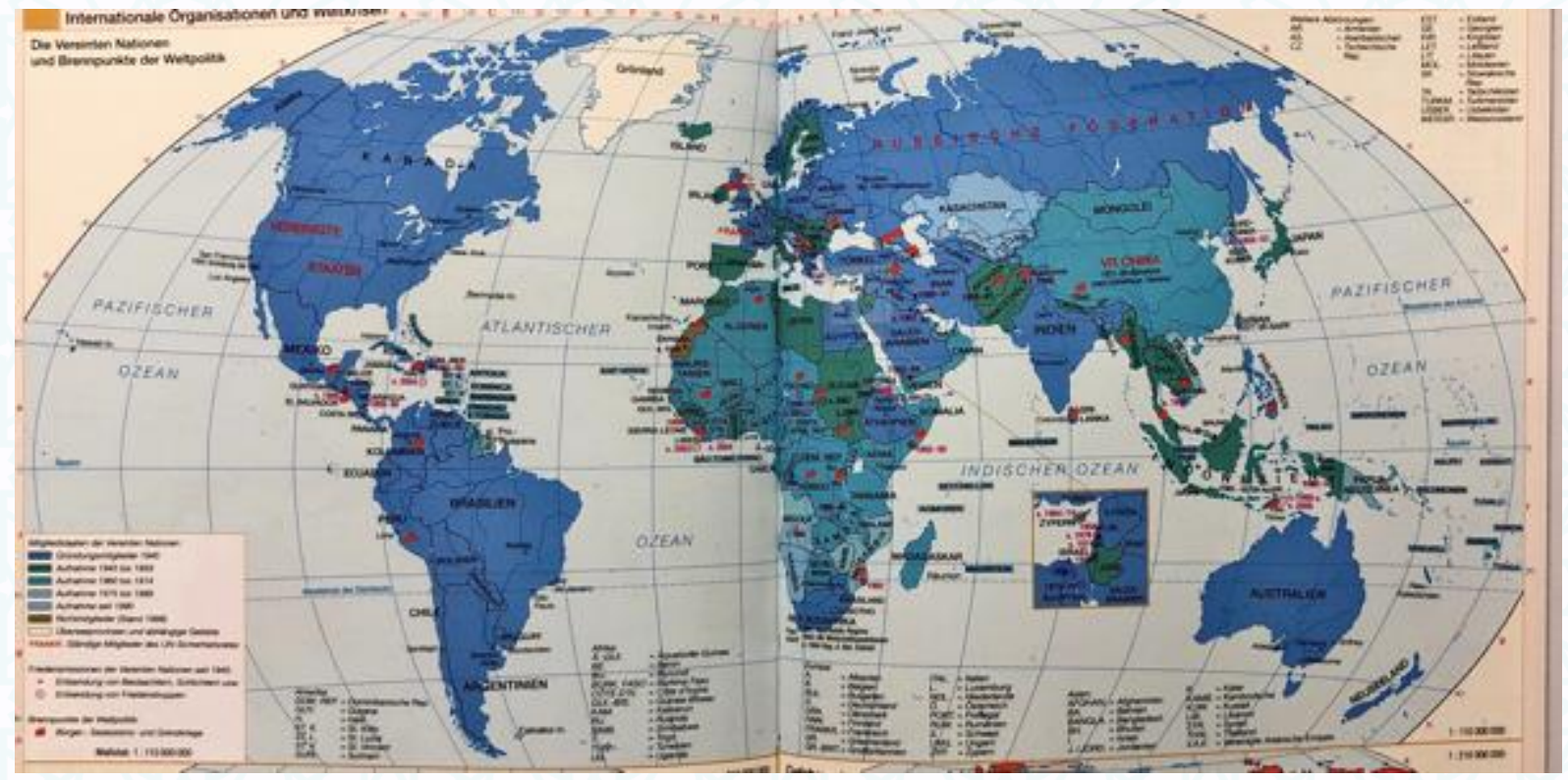

Bosatlas Van De Geschiedeniscanon (Hollanda) tarih atlasında ise Barış Operasyonları ve Hollanda'nın Katılımı adıyla bir harita (Şekil 29) sunulmaktadır. Bu haritada Hollanda'nın Birleşmiş Milletler bünyesinde 1950-2010 yılları arasında asker gönderdiği yerler konu edilmiştir:

Şekil 29. Barış Operasyonları ve Hollanda'nın Katılımı, Bosatlas Van De Geschiedeniscanon, Hollanda (2008)

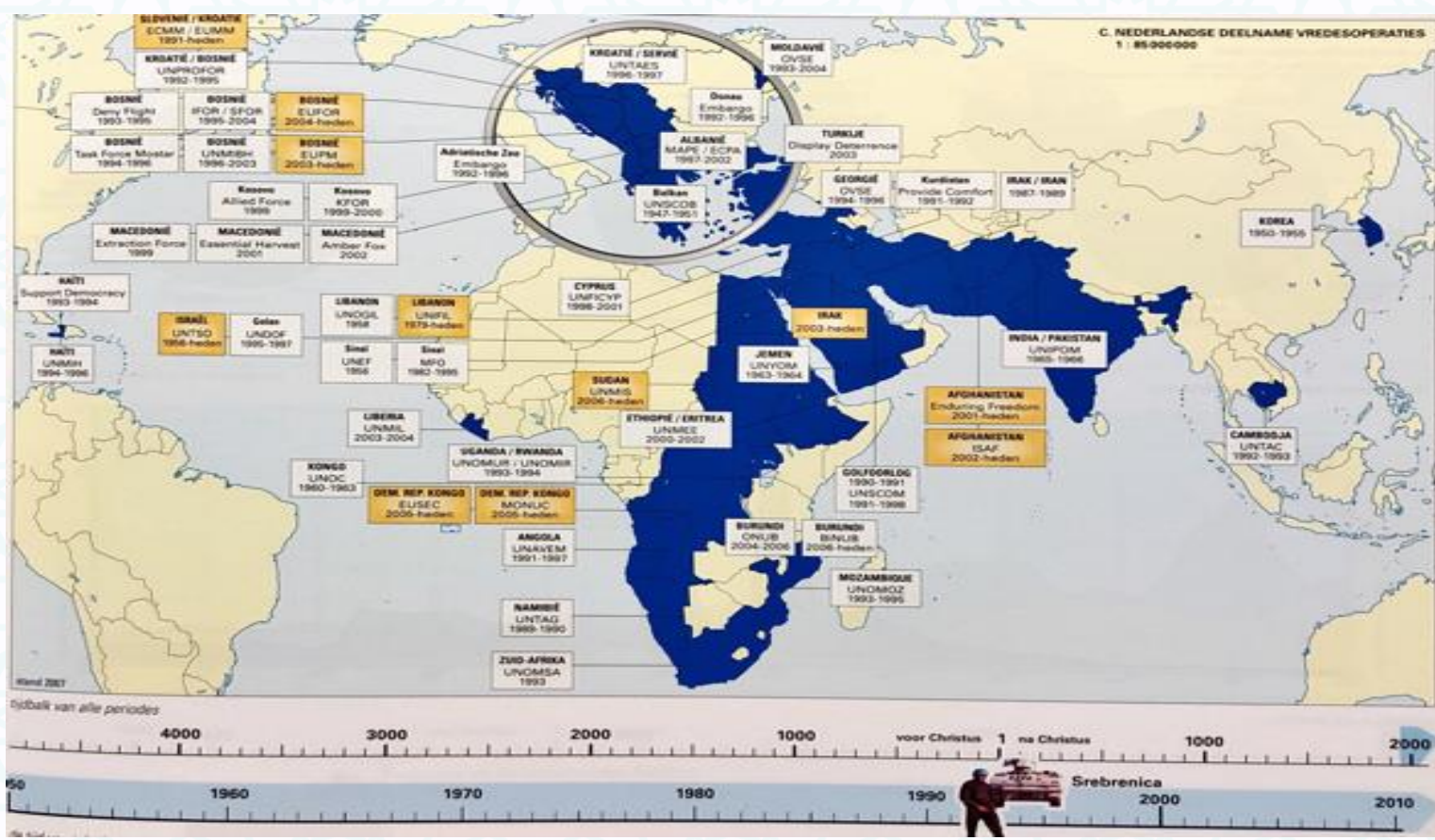




\section{Nüfus}

Tarih atlaslarında nüfus, nüfus hareketleri de yer almaktadır. Bu haritalarda nüfusun yıllara göre artışı anlatılabildiği gibi göç hareketleri de sunulabilmektedir:

Şekil 30. Nüfus, Atlas Vicens Vives De Historia, İspanya (2008)

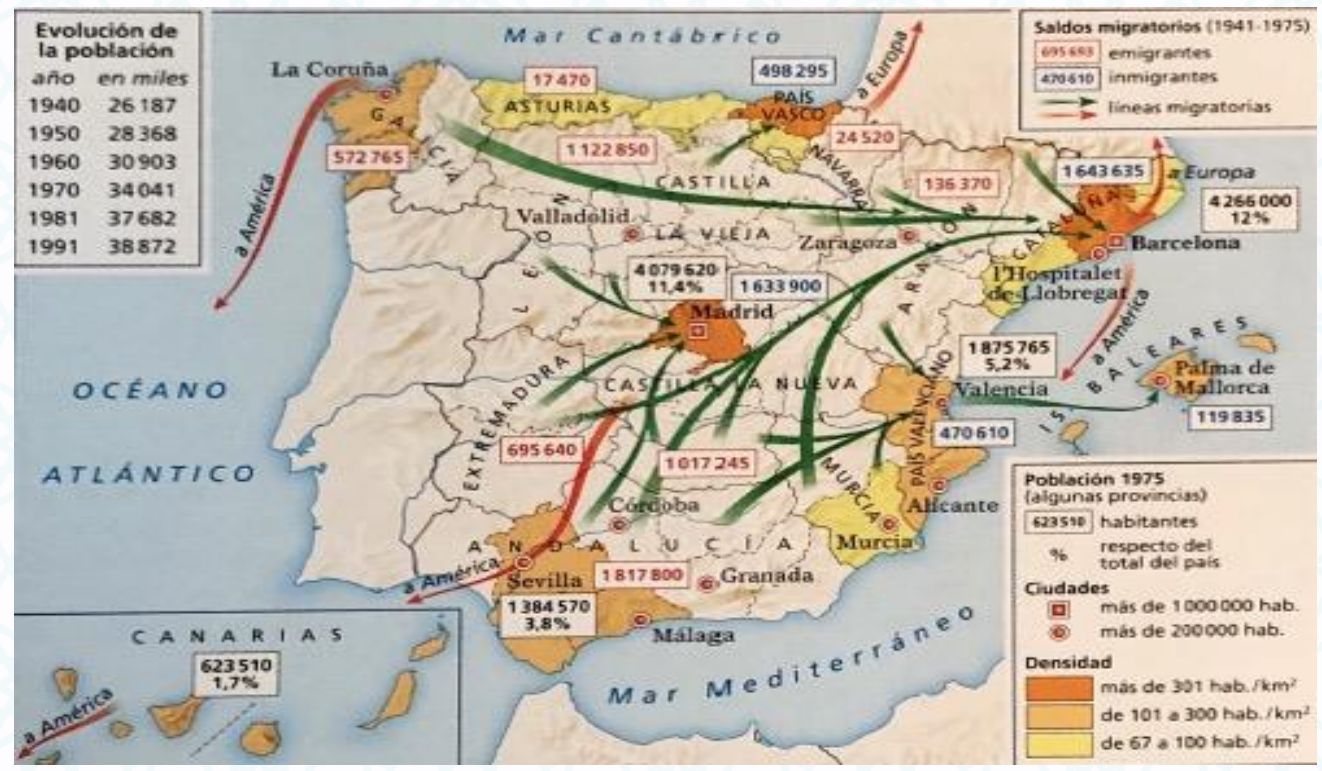

Şekil 30'daki haritada İspanya'da 1940 ile 1975 yılları arasında yaşanan nüfus hareketleri konu edilmektedir. Bu haritada nüfus alan yerler ve nüfus veren yerler de bir arada gösterilmiş, nüfusun hareket yönü net olarak sunulmuştur.

Atlas d'Histoire (Belçika)'da 1990'dan itibaren dünyada yaşanan nüfus hareketleri konu edilmektedir (Şekil 31). Haritada kıtalar arasındaki göç hareketleri, hangi kıtaların göç aldığı ve hangilerinin verdiği, nitelikli (beyin göçü) ve niteliksiz göç hareketleri bir arada sunulmuştur:

Şekil 31. 1990'dan Günümüze Dünya: Demografik Konular, Atlas d'Histoire, Belçika (2006). 


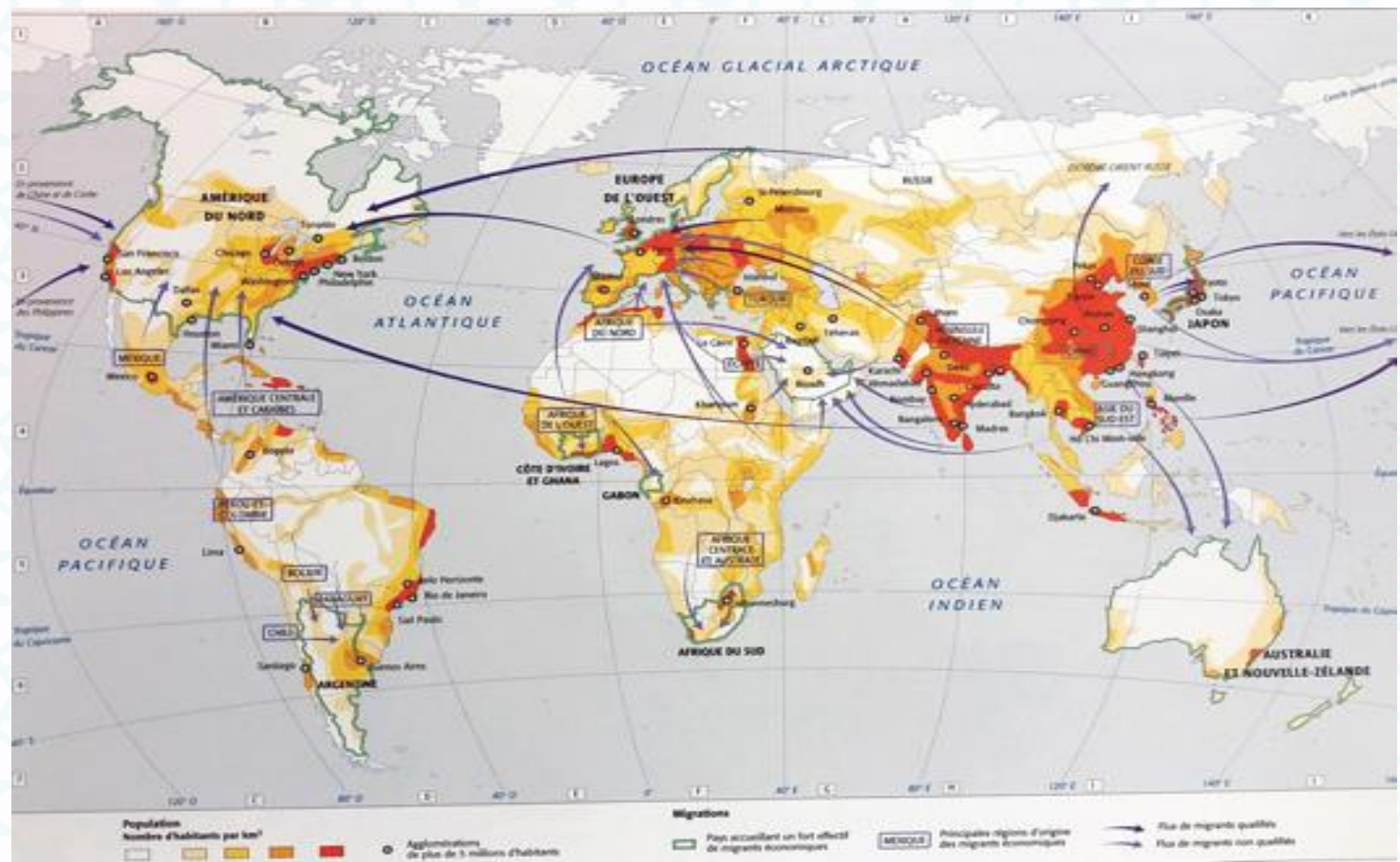

\section{Günümüz Dünya Sorunları}

Günümüzün önde gelen sorunlarından iklim değişimi ve çevre sorunu, göç hareketleri ve nükleer enerji gibi konuları anlatan haritalar da tarih atlaslarında yer almaktadır. Atlas Vicens Vives De Historia (İspanya)'da 1958-2007 yılları arasında iklim değişikliği ve ekolojik sorunları anlatan bir harita (Şekil 32) yer almaktadır. Haritada geniş ormansızlaştırma alanları, asit yağmuru etki alanları ve kirli deniz alanları gösterilmektedir. Ayrıca 1950-2000 yılları arasında toplam karbondioksit emisyonunu da haritada sunulmaktadır. Böyle bir haritanın tarih atlasında yer alması tarihin konu çeşitliliğini göstermesi açısından da oldukça ilgi çekicidir:

Şekil 32: İklim Değişikliği ve Ekolojik Sorunlar (1958-2007), Atlas Vicens Vives De Historia, İspanya (2008)

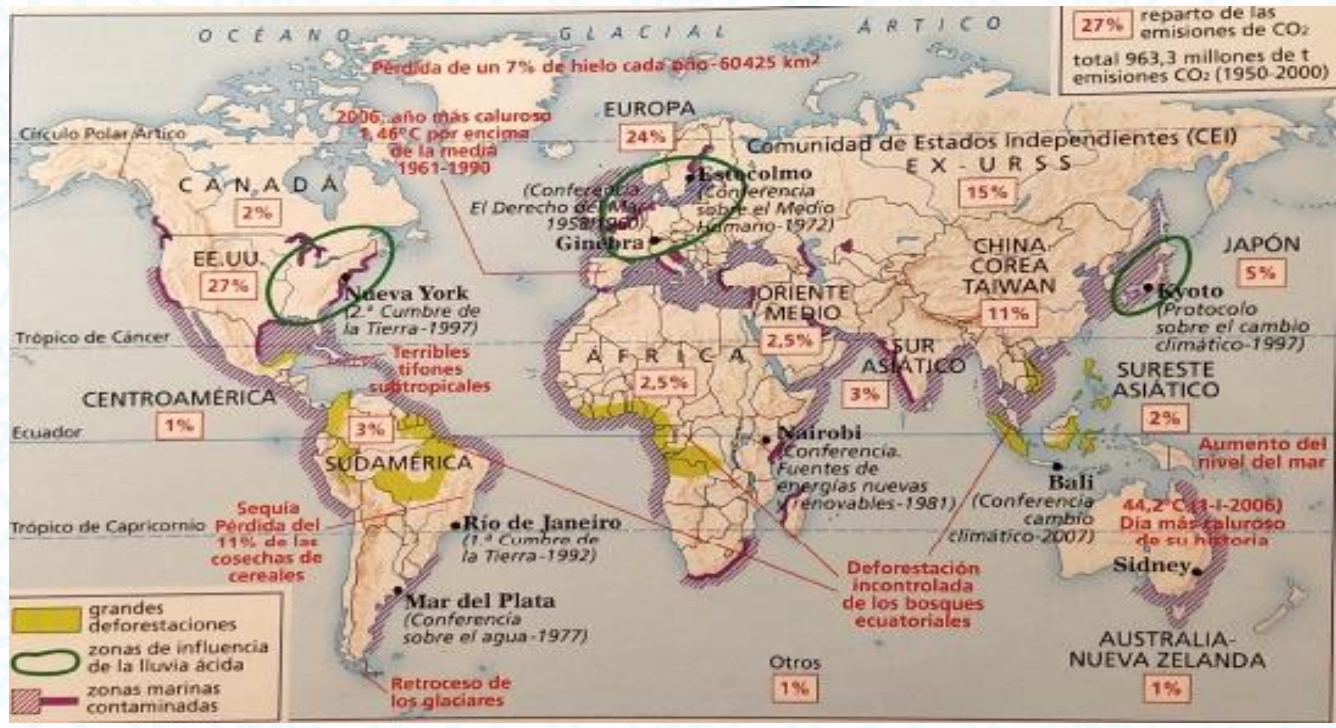

Putzger Historischer Weltatlas Kartenauzgabe (İsviçre) tarih atlasında ise günümüzün diğer bir sorunu mülteciler, ekonomik göç ve kentleşme konusu hakkında bir harita (Şekil 33) 
yer almaktadır. Haritada nerelerden nerelere göç hareketlerinin olduğu, göç hareketlerinin türü, nerelerde mülteci hareketlerinin olduğu gibi bilgileri görmek mümkündür:

Şekil 33. Siyasi Mülteciler, Ekonomi Göçü ve Kentleşme, Putzger Historischer Weltatlas Kartenauzgabe, İsviçre (2012)

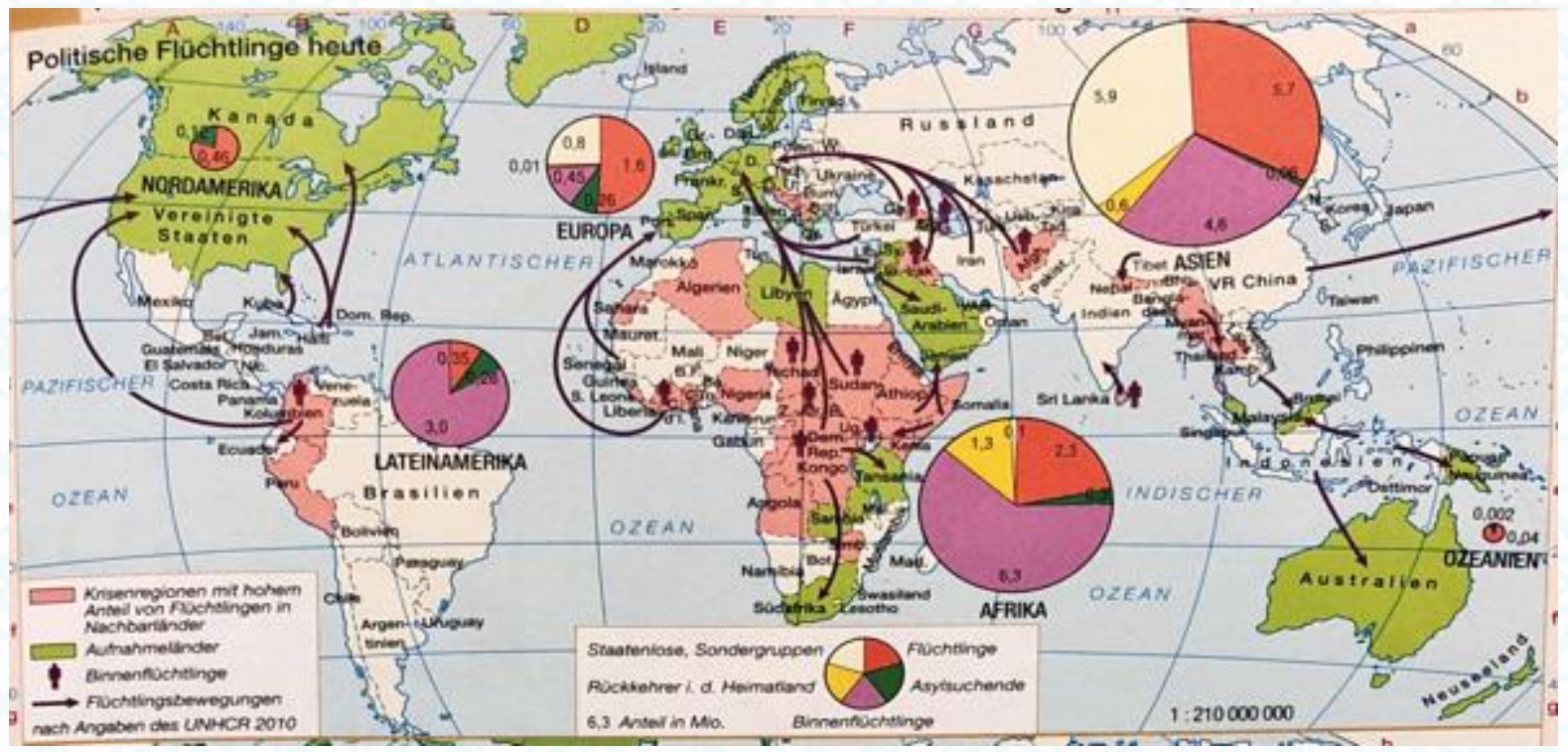

Putzger Historischer Weltatlas Kartenauzgabe (İsviçre) tarih atlasında nükleer enerji kullanımı hakkında da bir harita (Şekil 34) yer almaktadır. Haritada dünyada nükleer enerji kullanımları, yeni ve eski nükleer santraller, önemli nükleer kazalar gösterilmektedir:

Şekil 34. Atomik Çağın Tehlikeleri, Putzger Historischer Weltatlas Kartenauzgabe, İsviçre (2012)

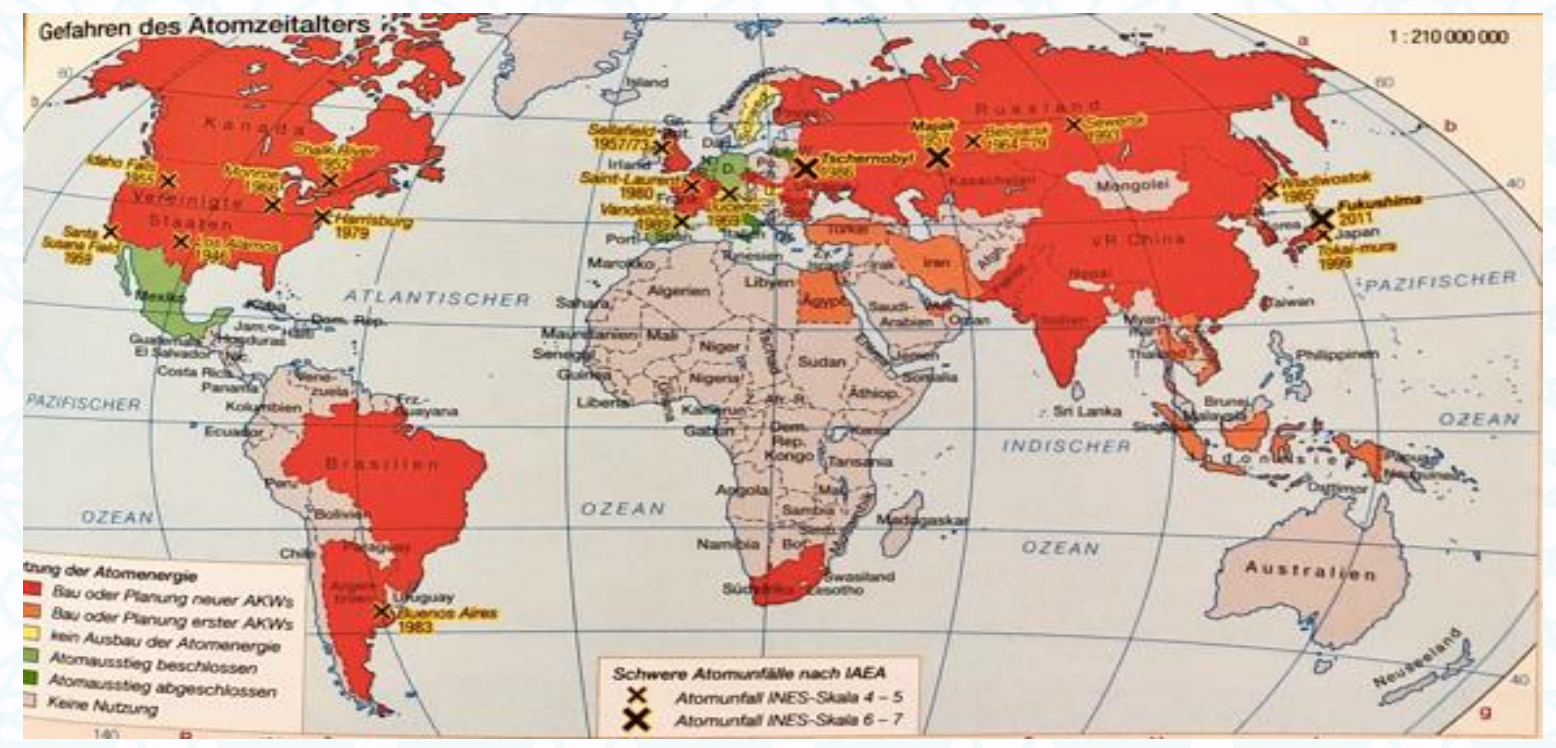

\section{Sonuç}


Tarih atlasları tarih öğretiminde akla gelen ilk yardımcı kaynaklardandır. Bir tarih haritası, öğrenciyi metin içerisinden çıkararak bahsedilen olay ya da olgunun mekânsal, zamansal ve ilişkisel boyutlarını görsel olarak öğrenciye özetler.

Bir olay ya da temayı haritalaştırmak; görselleştirme, kavramsallaştırma, bilgiyi düzenleme, temsil etme ve grafikleştirme aşamalarını içermektedir. Bu bakımdan öğrenci harita okuması sırasında analiz ve yorumlama becerisini ortaya koyar. Haritada kullanılan sembollerin konu ile ilişkilendirilmesi ve yorumlanması, haritanın işaret ettiği yerin belirlenmesi, yerler arasındaki mesafelerin hesaplanması, bahsedilen yerin dünya üzerindeki konumu gibi etkinlikler harita okuma becerisinin gelişmesinde yardımcıdır. Haritada kullanılan tüm harita ögeleri öğrencinin konu hakkında farklı bakış açıları üretmesini sağlar.

Ortaöğretim Tarih Dersi Öğretim Programı (2018) alana özgü yeterlik ve beceriler kısmında "Değişim ve Sürekliliği Algılama Becerisi" ve Sosyal Bilgiler Dersi Öğretim Programı (2018)'nda yer alan temel beceriden "mekânı algılama", "değişim ve sürekliliği algılama", "harita okuryazarlığı" ve "zaman ve kronolojiyi algılama" becerilerinin geliştirilmesinde tarih haritalarının önemli rol oynayabileceği düşünülebilir. Bu bakımdan çalışmada sunulan örneklerin ülkemiz tarih öğretiminde kullanılan haritalarla kıyaslanması gerekmektedir. Alıştığımız tarih haritaları devletlerin siyasi tarihlerini içeren savaş ve anlaşma, kuruluş ve yıkılma, gelişme ya da fetih hareketlerini konu edinmektedir. Çalışmada sunulan örnekler ise alfabe, teknolojik gelişmeler, insan faaliyetleri, salgın hastalıklar gibi devletlerin siyasi tarihlerinin çok dışında konulardır. Bu haritalarda belirli bir temaya bütüncül bakılmaya çalışılmıştır. Örneğin alfabe haritalarında tüm alfabe türlerinin ortaya çıkışları, yayılma yönleri ve birbirleriyle etkileşimleri sunulmuştur.

Incelenen tarih atlaslarında alfabe haritalarından teknolojik gelişmelere, insan faaliyetlerinden salgın hastalıklara belirli bir konunun yere ve zamana bağlı olarak bütüncül bakış açıları ön plana çıkmaktadır. Bu durum öğrencinin görselleştirilen konu hakkında genel bir fikir edinmesini de sağlamaktadır. Sunulan haritalarda öğrencinin ön bilgilerine ihtiyaç duyulmadan da bir konunun anlatılabileceği anlaşılmaktadır.

Çalışmada yer alan haritalar her sınıf düzeyi için aynı konunun farklı şekillerde sunulduğunu göstermektedir. Bu bakımdan öğrencilerin yaş ve seviyelerine göre tarih haritalarının hazırlanması gerekmektedir. Incelenen atlaslarda her konu ilkokul düzeyinden lise düzeyine kadar farklı semboller ve bilgi yoğunluğuna göre anlatılabilmektedir. Illkokul düzeyindeki tarih haritalarında daha fazla küçük resim ve canlandırmalar yer alırken lise ve daha üst düzeydeki haritalarda küçük canlandırmalar ve resimler ortadan kalkmakta yerine bir haritada olması gereken tüm harita özellikleri almaktadır. Bu durumda ülkemizde önemi göz ardı edilmiş olan tarih atlaslarının gözden geçirilerek her düzey için düzenlenmesi gerekmektedir.

Bu çalışma atlasçılığın çok zor ve emek isteyen bir alan olduğunu da göstermektedir. Putzger gibi atlasların bir atlasçılık geleneğinden geldiği düşünüldüğünde, ülkemizde bu alandaki boşluk göze çarpmaktadır. Sadece okullarda yardımcı materyal olarak kullanılan tarih 
atlaslarından çıkılmalı, bu alanın okurlarının sadece öğrenciler olmadığı göz önünde bulundurularak ülkemizde de tarih atlaslarının geliştirilmesine önem verilmelidir.

\section{Kaynakça}

Adams, X. (2004). Historische Atlas. Wommelgen: Van In.

Akengin, H. (2015). Tarih Öğretiminde Kullanılan Haritalar Üzerine Bir Deneme. Turkish History Education Journal (TUHED), 4 (1); s. 122-155.

Ata, B. (2009). Tarihçi Faik Reşit Unat'ın Milli Eğitime ve Tarih Eğitimine Katkıları. Türk Yurdu, Nisan 260; s. 94-101.

Atlas Historique. (2000). François Lebrun (Ed.). Paris: Hachette.

Bandrova, T. (2012), Cartographic Persponse to Changes in Teaching Geography and History. Maps for the Future: Children, Education and Internet (s. 203-217). L. Zentai ve J.R. Nunez (Eds.). Heidelberg, Dordrecht, London, New York: Springer.

Boehm, R.G. (2004). Building Geography Skills for Life. Student Text Workbook. Ohio: Glencoe McGraw-Hill.

Bosatlas van de Wereld-geschiedenis. (2009). 3.ed. Groningen: Wolters-Noordhoff Atlasproduktuies.

Britt Stems $\phi$, M. (2004). Cappelens Historiske Atlas. Oslo: Cappelens.

Hajkiewicz, I., Konopska, B. ve Prybytek, D. (2009). Atlas Historyczny, od starożytności do współczesności. Warszawa: Nowa Era.

Henningsen, K. (1998). Historisk Atlas. Brenderup: Georgrafforl.

Képes Történelmi Atlasz. (2001). Macaristan.

Középiskolai Történelmi Atlasz. (1998). (Szerk: Papp-Vary Arpad..). Budapest: Cartographia.

Maresz T., Olczak, E. ve Kubiz, B. (2007). Spotkania z Historia: atlas z komantarzami źródłowymi dla gimnazyum. Warszawa: Demart.

Noja, T. ve Tavasani, P. (2000). Atlante di storia. 1.ed. Milano: Arnaldo Mondodori Scuola.

Obiol, J. R. (2008). Atlas Vicens Vives De Historia, Atlas De Historia: Vicens Vives. Instituto Cartográfico Latino, Barcelona.

Rentsch, J. ve Sauerlander, D. (2012). Putzger Historischer Weltatlas Kartenausgabe. Berlin: Sauerlander Cornelsen.

Rentsch, J. ve Sauerlander, D. (2004). Putzger Historischer Weltatlas Schweizer Ausgabe. Berlin: Sauerlander Cornelsen.

Smart, L. (2004). Maps That Made History: The influental, the eccentric and the sublime. Toronto: Dundurn. 
Tulasne, J. (2015). Apprendre I'histoire avec un atlas: L'atlas historique, généalogique, chronologique et géographique de Lesage. UFR DE Georaphie, Master 1 De Geographie, Université Paris 1, Panthéon Sorbonne. Paris.

Viduramžiai: Atlasas Konspektas Žodynas. (2010). Vilnius: Briedis.

Wiegand, P. (2006). Learning and Teaching with Maps. New York: Routledge.

ИСТОРИЈСКИ АТЛАС. (2008). Sırbistan. 